\title{
BÎBLIYOGRAFYAYA TEZÊN MASTERÊ YÊN BEŞÊN ZIMAN Û EDEBIYATA KURDÎ Û ZIMAN Û ÇANDA KURDî (2011-2018)
}

\author{
Yakup Aykaç* \\ Şerif Güzel** \\ Sinan Çakar***
}

\section{Kurte}

Xebatên bîbliyografî̀k lêkolînên wisa ne ku xebatên di warekî de çêbûne bi awayekî sîstematîk berhev û dabeș dikin. Bi saya van xebatan karê lêkolîneran hêsantir dibe û zêdetir paşeroja xwe dibînin. Ev gotar jî xebateke bîbliyografîk e ku armanca vê gotarê nirxandineke giştî û dabeşkirineke kategorîk a tezên masterê yên beşên kurdî ye. Sînorên vê xebatê di navbera salên 2011 û 2018yan de tezên Ziman û Edebiyata Kurdî û Ziman û Çanda Kurdî yên li Tirkiyeyê ne. Ji ber ku di nav wan salan de li Tirkiyeyê hê tezên doktorayê kuta nebûbûn, lewma di vê xebatê de cih negirtine. Bi xêra vê bîbliyografyayê em ê pê bidine zanîn ku li ser kurdolojiyê bêtir li kîjan zanîngehê di kîjan mijar û biwaran de xebat çêbûne. Me di dawiya vê xebatê de hem li gor kategoriyan hem jî li gor rêzkirina alfabetîk a paşnav-navan lîsteya hemû tezan pêşkêş kir.

Peyvên Sereke: bîbliyografya, tezên masterê yên kurdolojiyê, ziman û edebiyata kurdî, ziman û çanda kurdî, xebatên kurdolojiyê

\section{THE BIBLIOGRAPHY OF THE THESIS IN THE DEPARTMENTS OF KURDISH LANGUAGE AND LITERATURE AND KURDISH LANGUAGE AND CULTURE (2011-2018)}

\begin{abstract}
Bibliographic studies provide experience of a long time in a special field to the researchers in a systematic and regular manner. These studies make it easy for researchers to work in the field and see the future. This study, as a bibliographic one, firstly aims to categorize and evaluate the master's theses written in Kurdish departments. The study covers master's theses prepared between the Kurdish Language
\end{abstract}

Article Types/Makale Türü: Bibliographic Article/Bibliyografik Makale

Received/Makale Geliş Tarihi:23/06/2019, Accepted/Kabul Tarihi: 28/07/2019

Doi: $10.26791 /$ sarkiat.581438

* Lêkolîner, Beşa Ziman û Edebiyata Kurdî, Zanîngeha Mardin Artuklu, yakupaykac@artuklu.edu.tr

ORCID ID: https://orcid.org/0000-0002-2602-484X

** Öğr. Gör., Beşa Ziman û Edebiyata Kurdî, Zanîngeha Bingölê, serifguzel@ bingol.edu.tr

ORCID ID: https://orcid.org/0000-0003-3837-3155

*** Lêkolîner, Beşa Ziman û Çanda Kurdî, Zanîngeha Van Yüzüncü Yı1, sinancakar@yyu.edu.tr

ORCID ID: https://orcid.org/0000-0002-1088-5995 
and Culture with Kurdish Language and Literature Department in 2011 and 2018 in Turkey. As the given period include no PhD studies in Turkey, in this study there is not any section addressed in doctorate dissertations. This bibliographic article deals with what kind of studies are done in which field and which subjects are given importance in the field of Kurdology. Moreover, at the end of this bibliography, the thesis studies are categorically classified according to their subjects and listed according to the authors' surnames-names.

Keywords: bibliography, Kurdology, master's thesis in Kurdology, Kurdish Language and Culture, Kurdish Language and Literature

\section{KÜRT DİLİ VE EDEBİYATI İLE KÜRT DİLİ VE KÜLTÜRÜ BÖLÜMLERINNDE YAZILAN YÜKSEK LISANS TEZLERININ BIBBLIYOGRAFYASI (2011-2018)}

Öz

Bibliyografik çalışmalar özel bir alanda yıllarca oluşan birikimi sistemik ve düzenli bir şekilde araştırmacılara sunar. Bibliyografik çalışmalar sayesinde araştırmacıların çalıştıkları alanda işleri kolaylaşır ve ileriyi daha iyi görürler. Bu çalışma da bibliyografik bir çalışma olmakla birlikte ilk amacı Kürtçe bölümlerinde yazılan yüksek lisans tezlerinin kategorize edilmesi ve değerlendirilmesidir. Bu çalışmanın sınırları Türkiye'de bulunan Kürt Dili ve Kültürü ile Kürt Dili ve Edebiyatı bölümlerinde 2011 ile 2018 yılları arasında hazırlanmış olan yüksek lisans tezleridir. Mevcut yıllar arasında Türkiye'de mezkur bölümlerde henüz doktora çalışmaları bulunmadığından bu çalışmanın içerisinde doktora tezlerine değinilmemiştir. Bu bibliyografik makale ile Kürdoloji sahasında hangi üniversitede hangi alanda ne tür çalışmalar yapıldığ 1 ve hangi konulara ağırlık verildiği belirtilmiştir. Bununla beraber bu bibliyografyanın sonunda yapılan tez çalışmaları hem konularına göre kategorik olarak sınıflandırılmış hem de yazarların soyisim-isim sıralamasına göre listelenmiştir.

Anahtar Kelimeler: bibliyografya, Kürdoloji yüksek lisans tezleri, Kürt Dili ve Kültürü, Kürt Dili ve Edebiyatı, Kürdoloji çalışmaları

\section{DESTPÊK}

Bêjeya bîbliyografyayê ji biblion (pirtûk) û graphien (nivîsandin) a zimanê grekî pêk hatiye ku dûre şiklê bibliographieyê girtiye û li zimanên din belav bûye. Roja îro wek têgeheke zanistên civakî di wateya "daneheva navên pirtûkan" de tê bikaranîn". Di dîroka zanistê de cara ewil hekîmê navdar Galenos Klaudîus/Calinus (sedsala II.) di pirtûka xwe de ya bi navê De Libris Propriis hizra bîbliyografyayê di wateya lîsteya berheman de bi kar aniye (Malclès û Lhérîtîer, 2003: 13-21). Herwiha di erdnîgariya Îslamê de alimên misilman ev têgeh bi navên wek kitabiyat, esami'l-kutûb, 'ilmu' '1kutûb, ehwali' l-kutûb, fihrîst, kitabşinasî bi kar birine. Di dîroka Îslamê de di vê biwarê de gelek mînak hene ku el-Fihrîst a Îbn Nedîm (kd. 990), Keşfu'z-Zunûn a Katib Çelebî (kd. 1657) di vê biwarê da berhemên girîng in (Durmuş, 2002: 83; Adak û yd., 2017: 173). Ji bilî van, di akademiyayê da li şûna bîbliyografyayê bêjeya literature jî cihê xwe

\footnotetext{
${ }^{1}$ Ji bo etîmolojî û wateya bêjeyê lê bnr. https://www.etymonline.com/word/bibliography\#etymonline_v_11116 (08.03.2019); https://en.oxforddictionaries.com/definition/us/bibliography (08.03.2019);

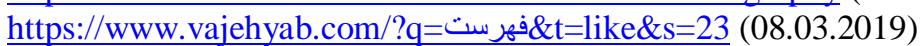


girtiye.

Bi demê re ji ber zêdebûna hejmara pirtûk, lêkolîn û xebatên nivîskî girîngiya bîbliyografyayê her ku çûye zêdetir bûye ku vê yekê jî di zanistên civakî de xebatên bîbliyografîk kiriye biwareke serbixwe. Ev xebatên bîbliyografyayê li gorî amadekirin û naveroka xwe tên dabeşkirin. Ya ewil bîbliyografyayên giştî ne ku di wan de sînorkirina mijar û babetan nîne. Ya din, bîbliyografyayên taybet in ku hem ji aliyê mijaran hem jî ji aliyê demê ve sînordar in û di biwareke taybet de lîteraturek ava dikin (Durmuş, 2002: 83-85). Di amadekirina bîbliyografyayan de mebesta yekem nasandin û diyarkirina lêkolîn û xebatên zanisteke taybet e. Dîsa bi saya xebatên bîbliyografîk lêkolîner wextê ku li ser mijarekê bixebite, pê dizane ku ka beriya wî di vê biwarê de çi hatiye kirin. Ev jî dike ku xebat dubare nebin û bi saya lêkolînên pêşîn xebatên hêjatir derkevin (Aykaç, 2017: 120-121).

\section{Kurtedîroka Beşên Ziman û Edebiyat/Çanda Kurdî}

Xebatên Kurdolojiyê yên akademîk li Tirkiyeyê bi awayekî fermî bi beşên Ziman û Çanda Kurdî dest pê kirin. Beşa Ziman û Çanda Kurdî cara yekem li Tirkiyeyê di sala 2009an de bi qanûn û biryara lijneya wezîran a Tirkiyeyê di binê Enstîtuya Zimanên Zindî yên Tirkiyeyê de digel beşa Ziman û Çanda Suryanî û Erebî li Zanîngeha Mardin Artukluyê vebû. Ev beş bi vekirina xwe re di sala 2010an de dest bi perwerdeya lîsansa bitez û bêtez kir û ji wê demê heta roja îro gelek kesan xebatên xwe yên akademîk li vir kirin. Dûre heman beş di sala 2012an de li zanîngehên Bîngol (li Çewlîgê), Mûş, Wan û Diyarbekirê jî vebûn. Beşa Ziman û Çanda Kurdî li Mêrdîn û Wanê di bin banê Enstîtuya Zimanên Zindî yên Tirkiyeyê de vebûn. Herwiha ya Bîngolê jî wisa bû lê beş ne bi navê çandê, bi navê Ziman û Edebiyata Kurdî vebû. Dîsa zanîngehên Diyarbekir û Mûşê jî beşên xwe di bin banê Enstîtuya Zanistên Civakî de vekirin. Di van zanîngehên navborî de pêşî li ser navê Enstîtuyên Zimanên Zindî bernameyên lîsansa bilind vebûn û ji beșên curbicur tezên mastirê hatin amadekirin. Dûre di hersê zanîngehên Mardîn Artuklu, Bîngol ${ }^{2}$ û Mûşê de beşên lîsansê jî vebûn. Herwiha niha li Zanîngeha Dîcle û wekî bernameya hevpar li herdu zanîngehên Bîngol û Mûş Alparslanê bernameyên doktorayê jî vebûn ${ }^{3}$ (Ertekin \& Güzel, 2019: 163-164; Keskin, 2018a: 476-477).

\section{Naverok û Nirxandina vê Xebatê}

Di van beşan de ji bilî tezan gelek xebatên akademîk yên wekî kovarên bi hakem ${ }^{4}$, proje, panel, sempozyum hwd. hatin kirin ${ }^{5}$. Piştî ku ev beş vebûn û wan xebatên akademîk kirin, ji ber zêdebûna tezên lîsansa bilind û nebûna arşîveke giştî, diviya ku xebateke bîblîyografîk bê kirin. Bi vê valahiyê cara ewil 2017an de bîbliyograyayek ji bo tezên lîsansa bilind ên beşa Ziman û Edebiyata Kurdî û Ziman û Çanda Kurdî hat

\footnotetext{
${ }^{2}$ Li Zanîngeha Bîngolê lisansa Ziman û Edebiyat Kurdî (Kurmancî) û Ziman û Edebiyata Zazakî bi hev ra vebûn. Herwiha beşa Ziman û Edebiyata Zazakî li Zanîngeha Munzûr (li Dersîmê) jî heye. Lê ji ber ku bernameya lisansa bilind a Zanîngeha Munzûrê nîne, me di xebata xwe de behsa wê nekir. Ligel van, li Zanîngeha Siirt (li Sêrtê) jî beşa kurdî heye lê beş ne aktif e û xwendekaran jî nagire.

3 Tezên doktorayên kurdî cara ewil di sala 2019an de mezûn bûn, ji ber ku nakevin bin sînorên vê bîbliyografyayê, me ew daxîlî vê xebatê nekirin.

${ }^{4}$ Li ser kovargeriya akademîk a kurdî li Turkiyeyê bnr. Keskin, "Kovargeriya Akademîk a Kurdî li Turkiyeyê û Pirsgirêkên Wê”, Mukaddime, j. 9 (2), 2018, r, 31-47.

5 Ji bo nirxandineke giştî ya akademiya kurdî ya Turkiyeyê lê bnr. Keskin, "Serboriya Akademiya Kurdî li Turkiyeyê û Pirsgirêkên Wê", e-Şarkiyat, c. 10, j. 1(19)/Nisan 2018, s. 471-485; Xebatên derbarê kurdolojiyê de li Zanîngeha Bingölê çêbûne bi awayekî rêkûpêk di vê gotarê da heye, lê bnr. M. Zahir Ertekin \& Şerif Güzel, "Xebatên Kurdolojîyê li Zanîngeha Bingölê (2014-2018)", Mukaddime, 2019, 10(1), r. 161-193.
} 
amadekirin $^{6}$. Vê bîbliyografyayê tezên di salên 2011-2016an dihewand û piştî vê bîbliyografyayê di salên 2017 û 2018an de gelek tezên nû çêbûn. Ji ber vê yekê jî hewcehiya nûjenkirina vê xebatê hate der. Hêviya me ev e ku bi saya vê bîbliyograyayê kesên ku di vê biwarî de dixebitin û lêkolîn dikin dê agahdar bibin ka li pêşiya wan di van beşan de çi xebat çêbûne. Dîsa ev ê di diyarkirina mijara tezan de jî rêyekê bide pêşiya xwendekarên lîsansa bilind.

Di vê xebatê de me hewl da ku bîbliyografyayeke nû ya tezên beşên kurdolojiyê berhev bikin. Me di amadekirina vê bîbliyografyayê de rasterast ji arşîên zanîngehên ku beşa kurdî lê hene îstîfade kirin û lêgerînek li malpera Navenda Tezên Perwerdeya Bilind a Turkiyeyê (YÖK Tez Merkezi ${ }^{7}$ ) kir. Piştî ku me tez tesbît kirin û lîsteya wan derxistin me agahî û îstatîstîkên wan li gorî zanîngeh û sal, ziman/zarave û şaxezanistên kurdolojiyê diyar kirin û ew senifandin û di dawiya vê xebatê jî me hemû tez bi awayekî alfabetîk li gorî paşnavê lêkolîneran rêz kirin.

Li gorî vê bîbliyografiyayê tê dîtin ku li Zanîngeha Bingölê ${ }^{8} 48$ tez, li Zanîngeha Dicleyê 7 tez, li Zanîngeha Mardin Artukluyê 106 tez, li Zanîngeha Muş Alparslanê 18 tez û li Zanîngeha Van Yüzüncü Yilê 62 tez hatine amadekirin. Ev li ser tabloyê, li gorî sal û zanîngehên jê derçûne wekî li jêr in:

\begin{tabular}{|c|c|c|c|c|c|}
\hline & & Zanîngeha & Zanîngeha & Zanîngeha & Zanîngeha \\
\hline & \multirow[t]{2}{*}{ Bingöl $^{9}$} & \multirow[t]{2}{*}{ Dicle } & Mardin & Muş & Yüzüncü \\
\hline & & & Artuklu & Alparslan & Yll \\
\hline 2012 & - & - & 3 & - & - \\
\hline 2013 & - & - & 14 & - & - \\
\hline 2014 & 7 & - & 18 & - & - \\
\hline 2015 & 14 & - & 17 & 5 & 1 \\
\hline 2016 & 3 & 3 & 19 & 2 & 15 \\
\hline 2017 & 15 & 4 & 14 & 8 & 36 \\
\hline 2018 & 9 & - & 21 & 3 & 10 \\
\hline
\end{tabular}

Tablo 1: Hejmara tezên beşên kurdî li gor sal û zanîngehan

Em dikarin hejmara tezan li gor sal û zanîngehan wek grafîka xêzî li jêrê bidin. Li grafíka jêrîn dixuye ku hejmara tezan piştî 2014an her ku çûye zêdetir bûye. Dîsa li gor

\footnotetext{
${ }^{6}$ Ji bo vê bîbliyografyayê lê bnr. Aykaç, "Bîbliyografyaya Tezên Beşên Kurdolojiyê yên li Turkiyeyê (2011-2016)", JMS, c. 2/1, 2017, r. 119-132.

${ }^{7}$ https://tez.yok.gov.tr/UlusalTezMerkezi/ (01.03.2019).

${ }^{8}$ Li Zanîngeha Bingölê digel beşa Ziman û Edebiyata Kurdî, Ziman û Edebiyata Zazakî jî heye. Di vê bîbliyografyayê de me ev herdu beş wek hev qebûl kirin û ji hev cuda nekirin. Lewma hejmarên ku bi tezên Zanîngeha Bingölê re têkildar in yekûna tezên kurmancî û kurmancî/zazakî ne, pêkve ne.

${ }^{9}$ Me navê zanîngehan di hemû tablo û îstatîstîkan de bi awayekî resen/tirkî nivîsandin. Ji ber vê yekê, li şûna Bîngol yan jî Çewlîgê me rasterast Bingöl nivîsî, herwiha yên din jî bi vî awayî ne.
} 
vê grafîkê nirxandinek bê kirin li gor xwendekarên mezûn bûne, hingê mirov dikare bibêje yên ku bi awayekî bi îstîqrar her sal xwendekarên xwe mezûn kirine Zanîngeha Mardin Artuklu û Zanîngeha Dicle ne. Li aliyekî din, Zanîngeha Yüzüncü Yıl di nav van zanîngehan de bi bêîstîqrarbûna xwe derdîkeve pêş. Wekî ku ji grafíkê jî diyar dibe, tezên ji Yüzüncü Yilê derçûne di navbera salên 2015-2018yan de ji nişka ve zêde dibe û ferqa hejmara mezûnên wê di navbera salan de nêzîkî hev nîne.

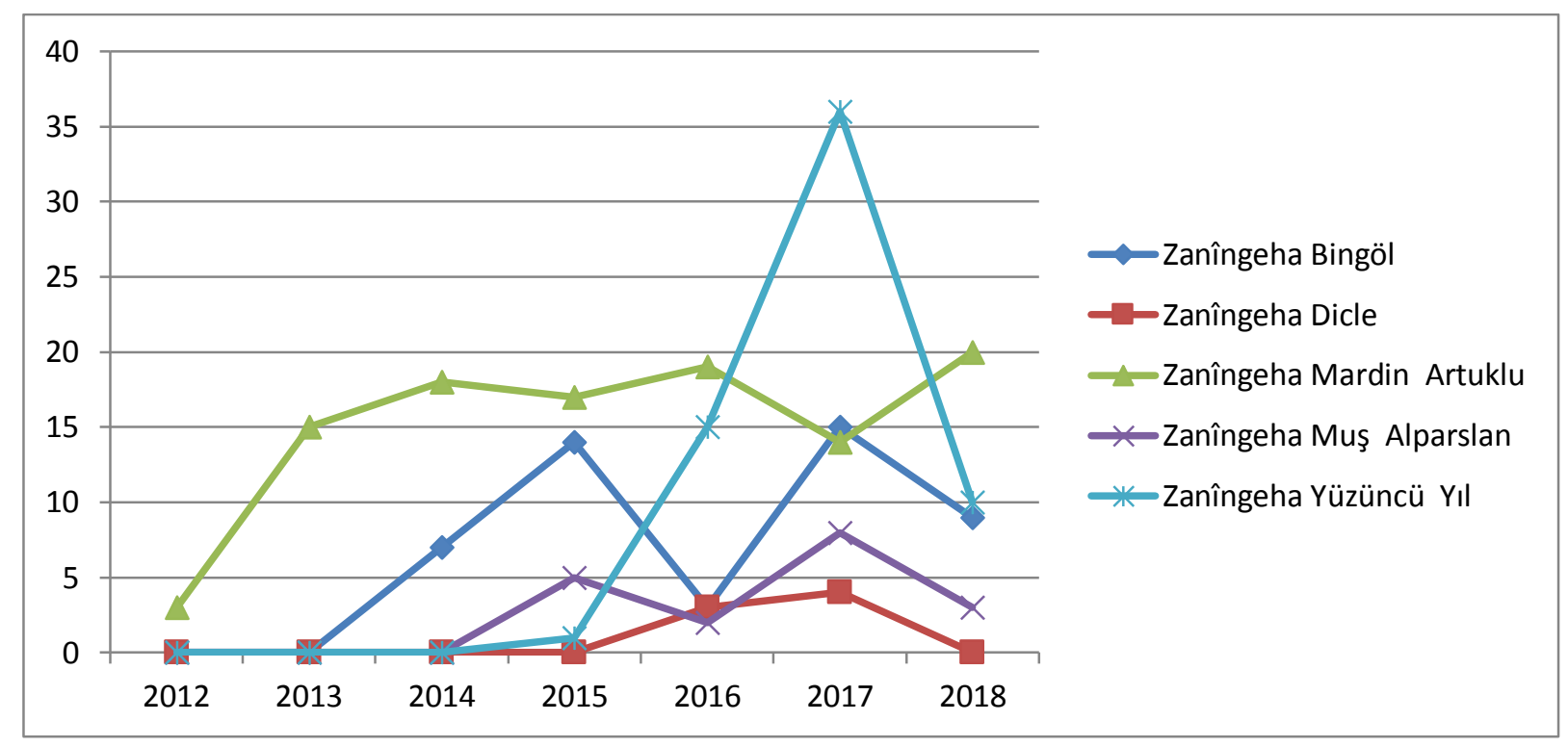

Grafîk 1: Tezên beşên kurdî li gor sal û zanîngehan

Tezên beşên Ziman û Çanda Kurdî û Ziman û Edebiyata Kurdî li jêrê li gor biwarên wan hatin tesnîfkirin. Di vê tesnîfê de biwarên ku cih girtine li gor mijar û naverokên tezan hatine danîn. Hinek tez li gor mijar û xebata xwe, ji ber ku xebatên wek navdîsîplînî bûn, di heman demê de di çend biwaran de cîh girtin. Di encamê de piştî nirxandina tezan me dabeşkirina biwarên tezên kurdî bi vî şiklî senifandin: Bîbliyografya (tezên bîbliyografîk), civaknasî, çapemenî, dîrok, edebiyata berawirdî, edebiyata klasîk, edebiyata nû, edebiyata zarokan, ferhengnasî, folklor, jînenîgerî, perwerde, wergernasî û zimannasî. Tabloya jêrê jî di kîjan zanîngehê de çend tez hene pêşanî me dike.

\begin{tabular}{lllll}
\hline Zanîngeha & Zanîngeha & Zanîngeha & Zanîngeha & Zanîngeha \\
Bingöl & Dicle & Mardin & Muş & Yüzüncü \\
\hline
\end{tabular}




\begin{tabular}{|c|c|c|c|c|c|}
\hline & & & Artuklu & Alparslan & Yll \\
\hline Bîbliyografya & 2 & - & 2 & - & - \\
\hline Civaknasî & - & - & 7 & - & - \\
\hline Çapemenî & 1 & - & 7 & 2 & 8 \\
\hline Dîrok & - & - & 4 & - & - \\
\hline $\begin{array}{l}\text { Edebiyata } \\
\text { Berawirdî }\end{array}$ & 1 & 1 & 2 & - & 2 \\
\hline $\begin{array}{l}\text { Edebiyata } \\
\text { Klasîk }\end{array}$ & 16 & 1 & 19 & 5 & 7 \\
\hline $\begin{array}{l}\text { Edebiyata } \\
\text { Nû }\end{array}$ & 4 & - & 36 & 3 & 34 \\
\hline $\begin{array}{l}\text { Edebiyata } \\
\text { Zarokan }\end{array}$ & 1 & - & 1 & - & 3 \\
\hline Ferhengnasî & 3 & - & - & 1 & - \\
\hline Folklor & 12 & 1 & 25 & 6 & 13 \\
\hline Jînenîgerî & - & 1 & 4 & 1 & - \\
\hline Perwerde & - & 1 & 5 & - & 3 \\
\hline Wergernasî & - & - & 1 & - & - \\
\hline Zimannasî & 11 & 3 & 22 & 4 & 5 \\
\hline
\end{tabular}

Tablo 2: Hejmara tezên beşên kurdî li gor biwar û zanîngehan.

Eger em van daneyan wek grafîk nîşan bidin dê wiha be: 


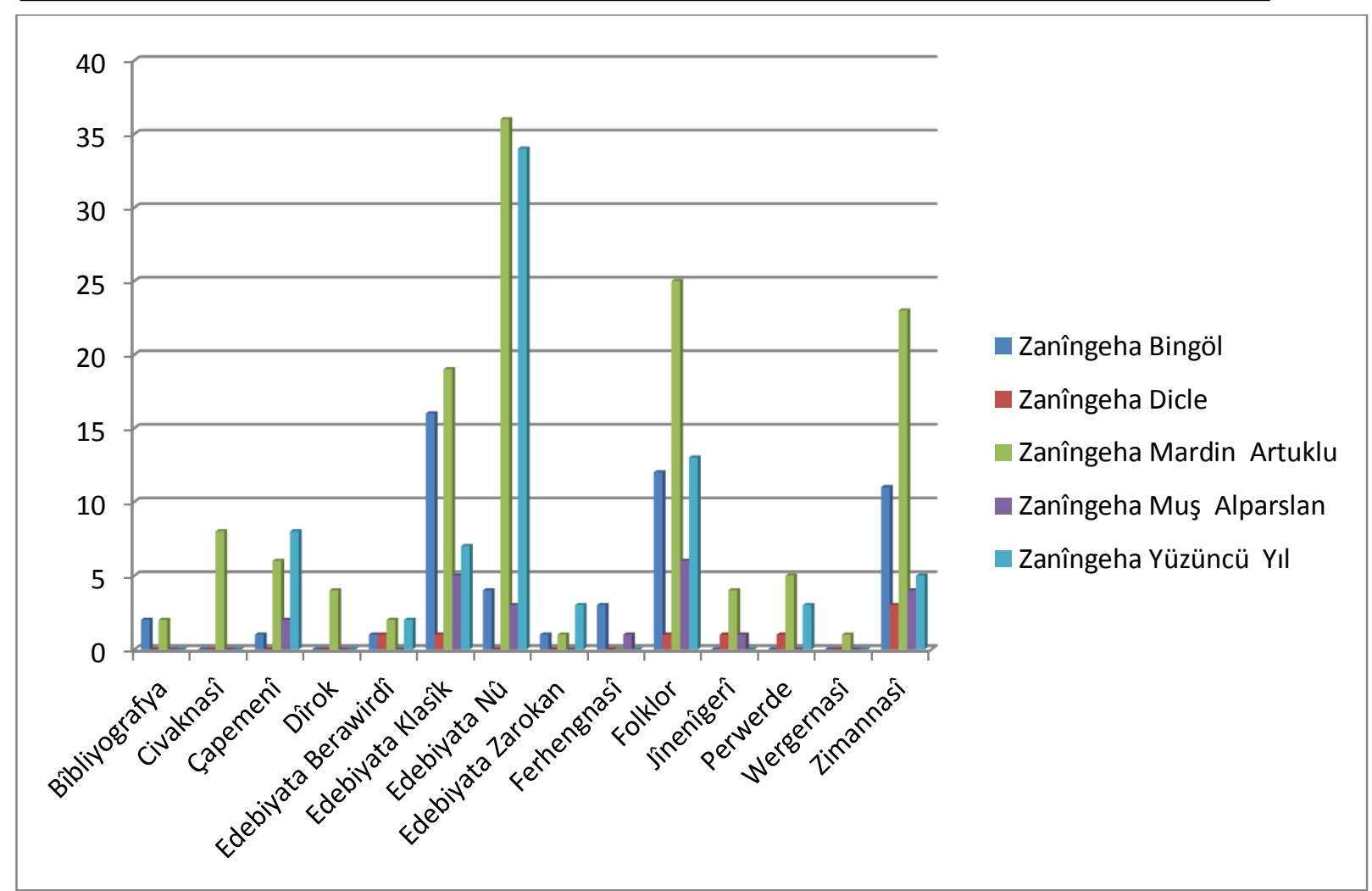

Grafîk 3: Tezên beşên kurdî li gor biwar û zanîngehan.

Mirov li gorî vê grafîka stûnî bi awayekî zelal dibîne ku di xebatên tezên masterên kurdî de biwara ku herî zêde hatiye tercîhkirin edebiyata nû ye. Dûre xwendekaran bi rêzê di biwarên folklor, edebiyata klasîk û zimannasiyê de tezên xwe nivîsîne. Ger em rêjeyên van biwaran destnîşan bikin dê grafîkeke wiha derkeve pêşiya me. 


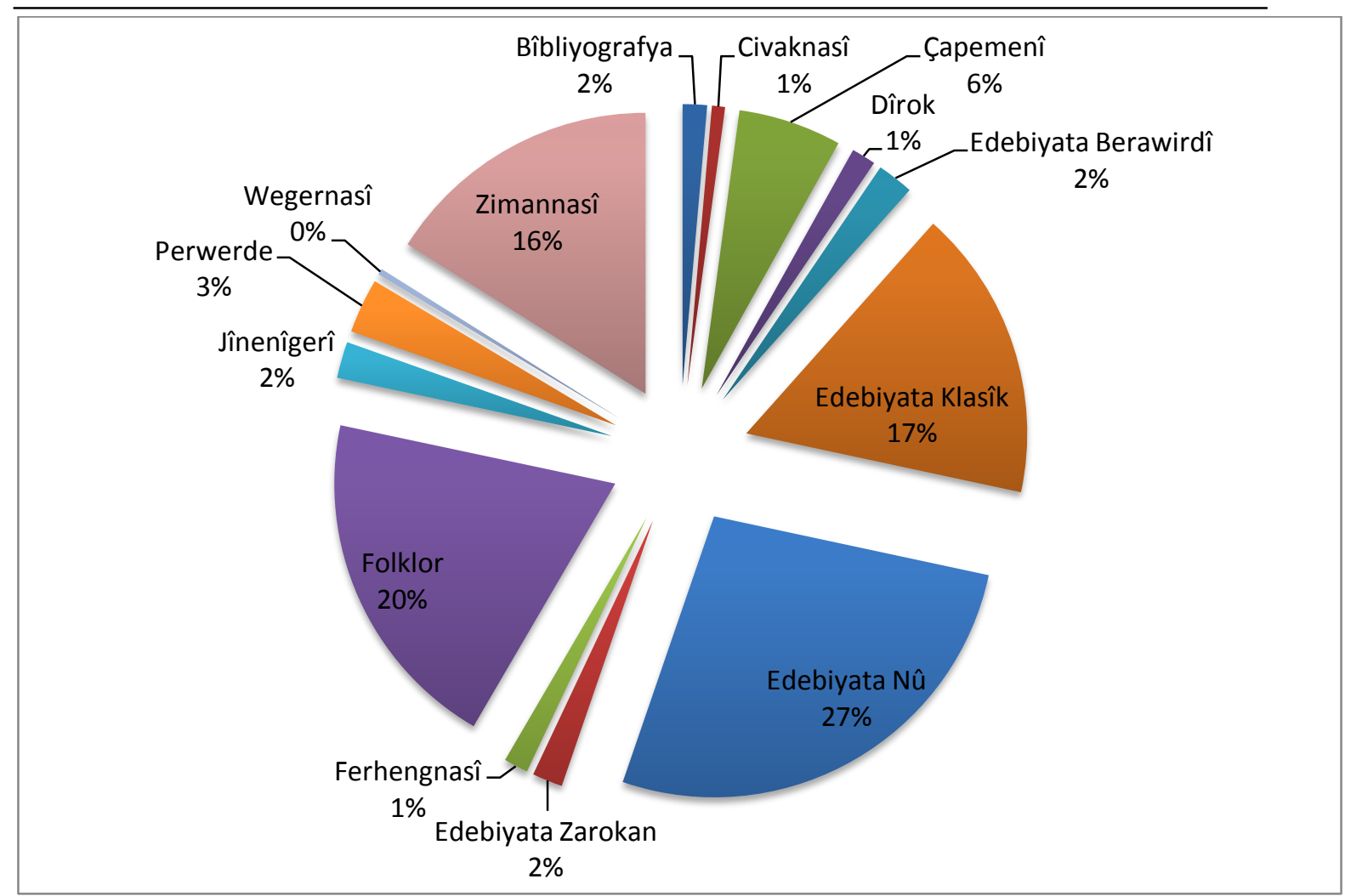

Grafik 3: Tezên beşên kurdî li gor rêjeya biwaran.

\section{Navên Tezan li gor Kategorîyan}

Li jêrê lîsteya tezan di bin van çardeh biwaran de hatiye dayîn ku ev kategorî jî bi rêzê ve ev in: Bîbliyografya, civaknasî, çapemenî, dîrok, edebiyata berawirdî, edebiyata klasîk, edebiyata nû, edebiyata zarokan, ferhengnasî, folklor, jînenîgerî, perwerde, wergernasî û zimannasî. Dîsa di bin van kategorîyan de berê paşnav û navê lêkolîner, navê tezê, navê zanîngehê, navê enstîtuyê, bajar û sal bi rêzê ve hatiye dayîn.

\subsection{Bîblîyografya}

Atlı, Zafer, Zeynelabidîn Zinar: Jiyan, Berhem û Senifandina Xebatên Wî, Zanîngeha Bingöl, Enstîtuya Zimanên Zindî, Çewlîg, 2018.

Başaran, Cahit, Kürt Dilinde Sözlükler, Zanîngeha Bingöl, Enstîtuya Zimanên Zindî, Çewlîg, 2014.

Can, Mutlu, Bîblîyografyaya Kirmanckî (Zazakî) (1963-2017), Zanîngeha Mardin Artuklu, Enstîtuya Zimanên Zindî, Mêrdîn, 2018.

Ekici, Abdullah, Zeynelabidînê Amidî: Jiyan Berhem û Xebatên Wî yên Destnivîsî, Zanîngeha Mardin Artuklu, Enstîtuya Zimanên Zindî, Mêrdîn, 2014.

\subsection{Civaknasî}

Ali Arif, Fakhir, Çavkaniya Jînwarparêzî ya Barzan, Zanîngeha Mardin Artuklu, Enstîtuya Zimanên Zindî, Mêrdîn, 2017.

Anuk, Nevzat, Behsê Tirkkerdișê Kurdan de Merkezêk: Enstîtuyê Cigerayîşê Kulturê Tirk, Zanîngeha Mardin Artuklu, Enstîtuya Zimanên Zindî, Mêrdîn, 2015.

Arslan, Mesut, Di Dewra Osmaniyan de Veşangeriya Kitêbên Kurdî (1844-1923), Zanîngeha Mardin Artuklu, Enstîtuya Zimanên Zindî, Mêrdîn, 2014. 
Bülbül, Mikail, Di Helbestên Cegerxwîn de Rengvedanên Têkiliyên Îqtîdarî, Zanîngeha Mardin Artuklu, Enstîtuya Zimanên Zindî, Mêrdîn, 2013.

Ergün, Zülküf, Di Peydabûna Edebiyata Kurdî ya li Cizîra Botan de Karîgeriya Bajarvaniyê, Zanîngeha Mardin Artuklu, Enstîtuya Zimanên Zindî, Mêrdîn, 2012.

Kerece, Fahrî, Di Çarçoveya Têgiha Neteweperwerîyê da Nirxandinek li ser Şêx Ubeydillahê Nehrî, Zanîngeha Mardin Artuklu, Enstîtuya Zimanên Zindî, Mêrdîn, 2018.

Saiwan Ahmed, Omar, Edebiyatî Enfal le Govare Kurdiyekanî Nawçeyî Germiyan da (1992-2012), Zanîngeha Mardin Artuklu, Enstîtuya Zimanên Zindî, Mêrdîn, 2016.

\section{3. Çapemenî}

Ali Mohammed, Ghalib, Rola Yusufî di Çapemeniya Kurdî de, Zanîngeha Yüzüncü Y1l, Enstîtuya Zimanên Zindî, Wan, 2017.

Arslan, Mesut, Di Dewra Osmaniyan de Veşangeriya Kitêbên Kurdî (1844-1923), Zanîngeha Mardin Artuklu, Enstîtuya Zimanên Zindî, Mêrdîn, 2014.

Balta, Adem, Rê û Rêbazên Nivisîna Nûçeyên Kurdî, Zanîngeha Muş Alparslan, Enstîtuya Zanistên Civakî, Mûş, 2017.

Çetin, Süleyman, Kovara Hawarê û Bandora Wê ya li ser Zimanê Kurdî, Zanîngeha Yüzüncü Y1l, Enstîtuya Zimanên Zindî, Wan, 2016.

Demiral Taher, İde, Perwerdeya Nirxên Çandî û Civakî di Kovargeriya Zarokan a Kurmancî-Latînî de (1980-2015), Zanîngeha Mardin Artuklu, Enstîtuya Zimanên Zindî, Mêrdîn, 2018.

Hikmat Ali Zada, Partiman, Rolê Govara Kepir di Pêşxistina Çîroka Zarokan de, Zanîngeha Mardin Artuklu, Enstîtuya Zimanên Zindî, Mêrdîn, 2018.

Hussain, Hunar M., Rollî Rageyandin le Nêzîkkirdnewey Diyalêkte Kurdyekan, Torî Mîdyayî Rudawû be Nimûne, Zanîngeha Mardin Artuklu, Enstîtuya Zimanên Zindî, Mêrdîn, 2015.

Ismael Khalid Zebari, Rabeea, Lêkolînek li ser Rexne ya Edebî (Kovara Peyv Weke Nûmûne), Zanîngeha Yüzüncü Y1l, Enstîtuya Zimanên Zindî, Wan, 2017.

Kan, Ahmet, Rojnameya Kurdistanê 1898-1902 (Analîza Naverokê), Zanîngeha Mardin Artuklu, Enstîtuya Zimanên Zindî, Mêrdîn, 2018.

Kanabi Taher, Barzan, Bas û Xwas Le Manşetî Hewal Rojnamekanî Xebat, Kurdistanî Nûwe û Rojname: Be Numûne Lêkolîneweyekî Simantîkî û Pragmatîkî, Zanîngeha Bingöl, Enstîtuya Zimanên Zindî, Çewlîg, 2018.

Karaaslan, Mehmet Salih, 'Hedersmord' li Swêdê 'Kuştina Namûsî' li Kurdistanê, Zanîngeha Mardin Artuklu, Enstîtuya Zimanên Zindî, Mêrdîn, 2014.

Khidhir, Mohammed, Ji bo Zarokan Çîrokên Ajalan (Mînak Çîrokên Kovara Heng 2001-2011), Zanîngeha Yüzüncü Y1l, Enstîtuya Zimanên Zindî, Wan, 2017.

Muhammed Mawlud, Qabeel, Rola Rojnama Bizav di Pêşxistina Helbesta Kurdî li Devera Behdînan, Zanîngeha Yüzüncü Y1l, Enstîtuya Zimanên Zindî, Wan, 2017.

Nori Omer, Salam, Rolê Kovara Metîn di Pêşxistina Vekolînên Edebî de, Zanîngeha Yüzüncü Y1l, Enstîtuya Zimanên Zindî, Wan, 2017. 
Othman Qader, Samad, Zimanê Ragihandinê di Nuçeyên Rojname Elektronîk de, Zanîngeha Yüzüncü Y1l, Enstîtuya Zimanên Zindî, Wan, 2017.

Öztürk, İrfan, Hîmên Helbesta Kovara Tîrêjê, Zanîngeha Mardin Artuklu, Enstîtuya Zimanên Zindî, Mêrdîn, 2014.

Saleh Hussein, Nadhim, Kovargeriya Zarokan li Başûrê Kurdistanê (Mînak: Kepir), Zanîngeha Yüzüncü Y1l, Enstîtuya Zimanên Zindî, Wan, 2018.

Yonat, Mehmet, Kovara Nûdemê û di Kovara Nûdemê de Şopên Surgunê, Zanîngeha Muş Alparslan, Enstîtuya Zanistên Civakî, Mûş, 2015.

\subsection{Dîrok}

Adak, Reşat, Di Serdema Meşrûtiyetê de Zanyarekî Kurd: Seîdê Kurdî û Hizr û Xîtabên Vî Derheqê Hişmendiya Gelê Kurd de, Zanîngeha Mardin Artuklu, Enstîtuya Zimanên Zindî, Mêrdîn, 2013.

Eyer, Ahmet, Kurdên Merwanî di Tarîxu'l-Meyafarqîn a Îbnu'l-Ezraq de, Zanîngeha Mardin Artuklu, Enstîtuya Zimanên Zindî, Mêrdîn, 2016.

Kerece, Fahrî, Di Çarçoveya Têgiha Neteweperwerîyê da Nirxandinek li ser Şêx Ubeydillahê Nehrî, Zanîngeha Mardin Artuklu, Enstîtuya Zimanên Zindî, Mêrdîn, 2018.

Ulugana, Sedat, Mîrektiya Bitlîsê di Êwra Evdal Xan de (1618-1664), Zanîngeha Mardin Artuklu, Enstîtuya Zimanên Zindî, Mêrdîn, 2015.

\subsection{Edebiyata Berawirdî}

Ibrahim Awla, Farman, Di Edebiyata Kurdî ya Kevin û Nû da Erkên Rexneyî, Zanîngeha Yüzüncü Y1l, Enstîtuya Zimanên Zindî, Wan, 2017.

Hawkar Jameel, Mohammed, Binyadî Gêranewa le Dastanî Mem û Zinî Oskar Mann û Şanoyî Memê Alanî Ebdurehîm Rehmî Hekarî (Lêkolînewekî Berawirdkariyê), Zanîngeha Bingöl, Enstîtuya Zimanên Zindî, Çewlîg, 2017.

Najeb Abdulrazaq, Jegr, Binyatê Honerî di Dastana Zembîlfroş ya Feqiyê Teyran û Miradxanê Bayezîlî da, Zanîngeha Mardin Artuklu, Enstîtuya Zimanên Zindî, Mêrdîn, 2017.

Shukur Mahmood, Imad, Têgeh û Zaravayê Îrfanî di Helbestên Fexredîn Eraqî û Mihwî de, Zanîngeha Yüzüncü Y1l, Enstîtuya Zimanên Zindî, Wan, 2017.

Tanrikulu, Veysel, Kürtçe Masallar ile Grimm Kardeşler Masallarının Motifler Açısından Karşılaştırılması, Zanîngeha Dicle, Enstîtuya Zanistên Civakî, Diyarbekir, 2017.

Yılmaz, Ferhat, Berawirdkirinek li ser Şivanê Kurmanca û Sêbareya Maksîm Gorkî, Zanîngeha Mardin Artuklu, Enstîtuya Zimanên Zindî, Mêrdîn, 2015.

\subsection{Edebiyata Klasîk}

Abdulhaleq Salahaldin, Barzi, Wêneya Helbestî di Helbestên Kurdî yên Mistefa Begê Kurdî da, Zanîngeha Yüzüncü Y1l, Enstîtuya Zimanên Zindî, Wan, 2017.

Ahmed Haji Abozaid, Bayar, Rengvedana Edebê Folklorî di Şiîrên Mela Xelîl Mişextî da, Zanîngeha Mardin Artuklu, Enstîtuya Zimanên Zindî, Mêrdîn, 2018.

Akboğa, Hasan, Xelîfe Yûsif û Teqrîza Wî (Metn û Lêkolîn), Zanîngeha Bingöl, Enstîtuya Zimanên Zindî, Çewlîg, 2017. 
Akın, Erkan, Mela Ehmedê Cizîrî’nin Gazellerinde Kullanılan Edebi Sanatlar, Zanîngeha Muş Alparslan, Enstîtuya Zanistên Civakî, Mûş, 2017.

Awla Rasul, Luqiman, Ciwankariya Peyvan di Helbestên Kurdî yên Salim de, Zanîngeha Yüzüncü Y1l, Enstîtuya Zimanên Zindî, Wan, 2017.

Aykaç, Seyfettin, Mela Mehmûdê Tîruwayî û Ferhenga Wî ya Menzûm (Metn û Lêkolîn), Zanîngeha Bingöl, Enstîtuya Zimanên Zindî, Çewlîg, 2016.

Aykaç, Yakup, Dîwana Hexin (Metn, Lêkolîn û Ferheng), Zanîngeha Bingöl, Enstîtuya Zimanên Zindî, Çewlîg, 2015.

Bakırhan, Cihat, Mele Nurullahê Godîşkî'nin 'Çenta Yetîman' Adlı Eserinin Transkripsiyonu, Türkçeye Çevirisi, Tahlil ve Tenkidi, Zanîngeha Muş Alparslan, Enstîtuya Zanistên Civakî, Mûş, 2017.

Beyter, Önder, Dîwana Mela Ehmedê Heyderî (Metn û Lêkolîn), Zanîngeha Mardin Artuklu, Enstîtuya Zimanên Zindî, Mêrdîn, 2013.

Çelik, Murat, 'Adat û Rusûmatname'ê Tewayifê Ekradiye ya Mela Mehmûdê Bazîdî, Zanîngeha Mardin Artuklu, Enstîtuya Zimanên Zindî, Mêrdîn, 2015.

Çiftçi, Metin, Eqîdenameyo Zazakî yê Mehemedê Hezanîyî (Metno Transkrîbekerde, Wekentiş û Açarnayîş), Zanîngeha Bingöl, Enstîtuya Zimanên Zindî, Çewlîg, 2015.

Dağılma, İbrahim, Mewlîdê Xasî û Hetê Me'na ra Wekentişê Mewlîdî, Zanîngeha Bingöl, Enstîtuya Zimanên Zindî, Çewlîg, 2017.

Delshad Saleh, Warin, Bekir Begê Erizî (Jiyan û Berhem), Zanîngeha Mardin Artuklu, Enstîtuya Zimanên Zindî, Mêrdîn, 2015.

Deniz, Muhammed İkbal, Jiyana Seyîd 'Eliyê Findikî û Dîwana Wî, Zanîngeha Bingöl, Enstîtuya Zimanên Zindî, Çewlîg, 2017.

Ekici, Abdullah, Zeynelabidînê Amidî: Jiyan Berhem û Xebatên Wî yên Destnivîsî, Zanîngeha Mardin Artuklu, Enstîtuya Zimanên Zindî, Mêrdîn, 2014.

Eminoğlu, Nevzat, Nêrînek Gelemperî li Mîrektiya Hîzanê: Îlm û Edebiyat, Zanîngeha Mardin Artuklu, Enstîtuya Zimanên Zindî, Mêrdîn, 2016.

Ergün, Zülküf, Di Peydabûna Edebiyata Kurdî ya li Cizîra Botan de Karîgeriya Bajarvaniyê, Zanîngeha Mardin Artuklu, Enstîtuya Zimanên Zindî, Mêrdîn, 2012.

Ertekin, Nurettin, Tesewif di Dîwana Şeyda de, Zanîngeha Bingöl, Enstîtuya Zimanên Zindî, Çewlîg, 2018.

Gezer, Semih, Dîwana Mela Yasîn Yusrî (Metn û Lêkolîn), Zanîngeha Bingöl, Enstîtuya Zimanên Zindî, Çewlîg, 2015.

Gider, Ahmet, Molla Muhammed Kavarî Dîvânı'nda Din ve Tasavvuf, Zanîngeha Bingöl, Enstîtuya Zimanên Zindî, Çewlîg, 2017.

Gözeten, İbrahim, Mele Xelîlê Sêrtî û Berhema Wi ya Newcû'l-Enam, Zanîngeha Muş Alparslan, Enstîtuya Zanistên Civakî, Mûş, 2015.

Heider Farhan, Hawkar, Xemilandina Felsefeya Oldariyê di Helbestên Mehwî de, Zanîngeha Yüzüncü Y1l, Enstîtuya Zimanên Zindî, Wan, 2017.

Hesan Kareem, Keywan, Eșq li cem Nalî, Zanîngeha Yüzüncü Y11, Enstîtuya Zimanên Zindî, Wan, 2017. 
İlhan, Ziver, Mewlûda Mela Huseynê Bateyî (Metn û Lêkolîn), Zanîngeha Mardin Artuklu, Enstîtuya Zimanên Zindî, Mêrdîn, 2013.

Jahany, Parviz, Leyla û Mecnûna Sewadî (Metin-Lêkolîn-Şîrove), Zanîngeha Mardin Artuklu, Enstîtuya Zimanên Zindî, Mêrdîn, 2015.

Karaman, Cevdet, Ehmed Hîlmî Elqoxî û Berhema Wî ya Rehberê Sanî Şerha Eqîda Ehmedê Xanî, Zanîngeha Muş Alparslan, Enstîtuya Zanistên Civakî, Mûş, 2017.

Kaya, Bülent, Feqîyê Teyran'ın Şêxê Sen'an Şiirinin İçerik Açısından İncelenmesi, Zanîngeha Dicle, Enstîtuya Zanistên Civakî, Diyarbekir, 2017.

Kurkan, Ahmet, Mewlîdê Usman Esad Efendîyo Babijî 'Bîyîşa Pêxemberî' (Metn û Vekenitîş), Zanîngeha Mardin Artuklu, Enstîtuya Zimanên Zindî, Mêrdîn, 2014.

Koyuncu, Hüseyin, Di Hin Dîwanên Kurdî de Bandora Tesewifê, Zanîngeha Bingöl, Enstîtuya Zimanên Zindî, Çewlîg, 2014.

Lafte Ridha Al-Kakî, Farset, Rengdanewey Taybetmendiyekanî Sebk-î 'Iraqî le Şi'rekanî Melayê Cizîrî da, Zanîngeha Bingöl, Enstîtuya Zimanên Zindî, Çewlîg, 2017.

Mohammed Othman, Hayder, Di Helbestên Melayê Bateyî da Binyada Hizr û Rûxsarê, Zanîngeha Yüzüncü Y1l, Enstîtuya Zimanên Zindî, Wan, 2016.

Naderî Moghadam, Shatav, Şi'rên Şairên Yarsan û Hizrê Yarî, Zanîngeha Yüzüncü Y1l, Enstîtuya Zimanên Zindî, Wan, 2016.

Najeb Abdulrazaq, Jegr, Binyatê Honerî di Dastana Zembîlfroş ya Feqiyê Teyran û Miradxanê Bayezîdî da, Zanîngeha Mardin Artuklu, Enstîtuya Zimanên Zindî, Mêrdîn, 2017.

Ölmez, Cumhur, Mem ̂̂ Zîneke bi Hewramî (Tekst-Vekolîn), Zanîngeha Mardin Artuklu, Enstîtuya Zimanên Zindî, Mêrdîn, 2018.

Omer Ahmad el Shateera, Koser, Şakelîyekan û Roliyan le Şi’rî Kurdî da; Şêx Ehmed be Nimûne, Zanîngeha Bingöl, Enstîtuya Zimanên Zindî, Çewlîg, 2018.

Orkin, Şeyhmus, Di Berhemên Feqiyê Teyran de Hêmanên Tesewufî, Zanîngeha Muş Alparslan, Enstîtuya Zanistên Civakî, Mûş, 2015.

Pertev, Ramazan, Mîrsadu'l-Etfal (Şahrahê Kûdekan) Ferhenga Menzûm a KurdîFarisî (Vekolîn-Tekst), Zanîngeha Mardin Artuklu, Enstîtuya Zimanên Zindî, Mêrdîn, 2012.

Sezer, Müslih, Dîwançeya Seyfiyê Şoşî (Metn û Lêkolîn), Zanîngeha Mardin Artuklu, Enstîtuya Zimanên Zindî, Mêrdîn, 2016.

Tahir Sabir, Derin, Şi'riyetî Şi'rî Kosarî, Zanîngeha Bingöl, Enstîtuya Zimanên Zindî, Çewlîg, 2018.

Turan, Cihan, Dîwana Fethî (Edîsyon, Metn, Krîtîk), Zanîngeha Bingöl, Enstîtuya Zimanên Zindî, Çewlîg, 2017.

Üneşi, Aydın, Tesrîfa Teremaxî, Zanîngeha Mardin Artuklu, Enstîtuya Zimanên Zindî, Mêrdîn, 2016.

Varol, Murat, Dîwanê Melayê Cebexçurî (Metn û Tehlîl), Zanîngeha Bingöl, Enstîtuya Zimanên Zindî, Çewlîg, 2016. 
Yavuzer, Mehmet Nur, Baba Tahir di Wêjeya Kurdî de, Zanîngeha Yüzüncü Yı1, Enstîtuya Zimanên Zindî, Wan, 2016.

Yergin, Mehmet, Mewlîdê Mela Ehmedê Xasî: "Mewlidu'n-Nebiyyi'l-Qureyşiyyî" (Metn-Wekenitiş), Zanîngeha Mardin Artuklu, Enstîtuya Zimanên Zindî, Mêrdîn, 2015.

Yeşilkaya, Şahap, Edebiyatê Kirdkî (Zazakî) de Mewlid û Mehemed 'Elî Hunî, Zanîngeha Bingöl, Enstîtuya Zimanên Zindî, Çewlîg, 2014.

Yıldız, Ayhan, Qewlê Hespê Reş, Zanîngeha Mardin Artuklu, Enstîtuya Zimanên Zindî, Mêrdîn, 2015.

Y1lmaz, Serdar, Dîwana Şêx Şemsedînê Exlatî Metin û Lêkolîn, Zanîngeha Mardin Artuklu, Enstîtuya Zimanên Zindî, Mêrdîn, 2013.

Zilan, Bilal, Di Kitabê Muhemmedê Şêx Ensarî: "Raro Raşt" û "Melûmatê Dînîye" (Metn û Cigêrayîş), Zanîngeha Mardin Artuklu, Enstîtuya Zimanên Zindî, Mêrdîn, 2016.

\subsection{Edebiyata Nû}

Abdullah Khudhur, Nali, Rexneya Civakî Di Helbestên Abdullah Paşêw de, Zanîngeha Yüzüncü Y1l, Enstîtuya Zimanên Zindî, Wan, 2016.

Acun, Roger, Îmaj di Helbesta Kurdî ya Nû ya Bakur de, Zanîngeha Mardin Artuklu, Enstîtuya Zimanên Zindî, Mêrdîn, 2016.

Adsay, Fahriye, Romana Kurdî (Kurmancî) ya Dîrokî: Bîra Civakî û Nasname, Zanîngeha Mardin Artuklu, Enstîtuya Zimanên Zindî, Mêrdîn, 2013.

Ahmed Mohammed, Arshad, Wataya Lawekî di Zimanê Romana Miryema da ya Sebrî Silêvanî, Zanîngeha Mardin Artuklu, Enstîtuya Zimanên Zindî, Mêrdîn, 2018.

Ali Mahmood, Yaseen, Xerîbî li Helbestên Hêmîn û Seyyab, Zanîngeha Yüzüncü Y1l, Enstîtuya Zimanên Zindî, Wan, 2017.

Ali Mohammed, Ghalib, Rola Yusufî di Çapemeniya Kurdî de, Zanîngeha Yüzüncü Y1, Enstîtuya Zimanên Zindî, Wan, 2017.

Altınkı1ıç, Ümran, Xwendineke Baxtînyen di Sê Romanên Kurdî de, Zanîngeha Mardin Artuklu, Enstîtuya Zimanên Zindî, Mêrdîn, 2015.

Aydoğdu, Yusuf, Modern Zaza Hikâyeciliği, Zanîngeha Bingöl, Enstîtuya Zimanên Zindî, Çewlîg, 2015.

Bilge, Evin, Ji Hêla Naverokê ve Dahûrîna Çîrokên Mela Mehmûdê Baẑdî, Zanîngeha Mardin Artuklu, Enstîtuya Zimanên Zindî, Mêrdîn, 2013.

Buran, Eşref, Mela Wekî Tîpekî Pêkenokên Kurdî, Zanîngeha Mardin Artuklu, Enstîtuya Zimanên Zindî, Mêrdîn, 2018.

Bülbül, Mikail, Di Helbestên Cegerxwîn de Rengvedanên Têkiliyên Îqtîdarî, Zanîngeha Mardin Artuklu, Enstîtuya Zimanên Zindî, Mêrdîn, 2013.

Çeçen, Ramazan, Di Edebiyata Kurdî de Folklor û Roman li dor Texeyyulên Berê Rêçên Îroyîn, Zanîngeha Mardin Artuklu, Enstîtuya Zimanên Zindî, Mêrdîn, 2013.

Çetin, Süleyman, Kovara Hawarê û Bandora Wê ya li ser Zimanê Kurdî, Zanîngeha Yüzüncü Y1l, Enstîtuya Zimanên Zindî, Wan, 2016. 
Çoban, Betül, Şopên Realîzma Sosyalist di Romanên Kurdî yên Sovyeta Berê de (1935-1991), Zanîngeha Mardin Artuklu, Enstîtuya Zimanên Zindî, Mêrdîn, 2017.

Dawood Fattah, Diler, Saloxdan di Mîrnameya Jan Dostî de, Zanîngeha Mardin Artuklu, Enstîtuya Zimanên Zindî, Mêrdîn, 2017.

Doğan, Songül, Bi Rêbaza Rexneya Femînîst Lênerînek li Romanên Jinên Kurd, Zanîngeha Mardin Artuklu, Enstîtuya Zimanên Zindî, Mêrdîn, 2018.

Döğer, Dilaver, Bêjara Neteweparêz di Kovara Hawarê de, Zanîngeha Yüzüncü Y11, Enstîtuya Zimanên Zindî, Wan, 2017.

Fahmi Farho, Karokh, Bingehê Vegotinê di romana 'Grêweya Bextê Helale'ya Eta Nehayî de, Zanîngeha Yüzüncü Y1l, Enstîtuya Zimanên Zindî, Wan, 2017.

Farhad Abdullah, Sardar, Nûjenxazî di Rûxsara Helbestên Şêx Nurî da, Zanîngeha Yüzüncü Y1l, Enstîtuya Zimanên Zindî, Wan, 2017.

Gören, Ebubekir, Di Romanên Erebê Şemo de Folklora Kurdî, Zanîngeha Mardin Artuklu, Enstîtuya Zimanên Zindî, Mêrdîn, 2013.

Haji Sulaiman, Hareem, Hozanetî di Hozanên Sebirî Botanî da, Zanîngeha Yüzüncü Y1l, Enstîtuya Zimanên Zindî, Wan, 2017.

Hassan Mawlood al-Bajalan, Hardi, Di Helbestên Hemîn Mukiryanî de Civaknasî, Zanîngeha Yüzüncü Y1l, Enstîtuya Zimanên Zindî, Wan, 2017.

Hikmat Ali Zada, Partiman, Rolê Govara Kepir di Pêşxistina Çîroka Zarokan de, Zanîngeha Mardin Artuklu, Enstîtuya Zimanên Zindî, Mêrdîn, 2018.

Hussein Abo, Reber, Çîroka Gelek Kurt di Edebê Kurdî da li Başûrê Kurdistanê (1991-2013), Zanîngeha Mardin Artuklu, Enstîtuya Zimanên Zindî, Mêrdîn, 2015.

Ibrahim Awla, Farman, Di Edebiyata Kurdî ya Kevin û Nû da Erkên Rexneyî, Zanîngeha Yüzüncü Y1l, Enstîtuya Zimanên Zindî, Wan, 2017.

Ibrahim Hami Kocher, Bangeen, Rexneya Civakî di Romanên Hesenê Metê da, Zanîngeha Mardin Artuklu, Enstîtuya Zimanên Zindî, Mêrdîn, 2014.

Ibrahim, Ibrahim, Rengvedana Dîroka Kurdî di Helbestên Cegerxwîn de, Zanîngeha Mardin Artuklu, Enstîtuya Zimanên Zindî, Mêrdîn, 2016.

Ismael Ahmed, Rabar, Teknîk di Deqên Şanoyên Tele’t Saman di Salên Heştêyan de, Zanîngeha Yüzüncü Y1l, Enstîtuya Zimanên Zindî, Wan, 2017.

Ismael Ahmed, Reband, Avahiya Derûnî ya Karekter di Romana Diwahemîn Henarî Dunya yê Bextiyar Elî de, Zanîngeha Yüzüncü Y1l, Enstîtuya Zimanên Zindî, Wan, 2017.

Ismael Ali, Saman, Vebêjin di Navbera Romana "Navê Min Sor e" ya Orhan Pamuk û "Mîrnameya" Can Dost e, Zanîngeha Yüzüncü Y1l, Enstîtuya Zimanên Zindî, Wan, 2017.

Ismael Khalid Zebari, Rabeea, Lêkolînek li ser Rexne ya Edebî (Kovara Peyv Weke Nûmûne), Zanîngeha Yüzüncü Yı1, Enstîtuya Zimanên Zindî, Wan, 2017.

Issa Ibrahim, Hayhat, Xweza di Helbestên Nû yên Kurdî de Helbestên Qadir Qeçax û Edîb Çelkî wek Nimûne, Zanîngeha Mardin Artuklu, Enstîtuya Zimanên Zindî, Mêrdîn, 2017. 
Işık, Burhan, Berhema Mehmed Uzun a Binavê Hawara Dîcleyê de Jiyana Kurdan a Civakî, Zanîngeha Muş Alparslan, Enstîtuya Zanistên Civakî, Mûş, 2015.

Jaafar Hussein, Shreen, Vênê Jinê di Hozana Hevçerxa Kurdî da, Zanîngeha Mardin Artuklu, Enstîtuya Zimanên Zindî, Mêrdîn, 2015.

Jalal Mohammed Amin, Dilshad, Ezmûna Teyyib Cebbar ya Helbest û Rexne, Zanîngeha Yüzüncü Y1l, Enstîtuya Zimanên Zindî, Wan, 2017.

Jameel Ismail, Abid, Rengvedana Geşbîniyê di Helbesta Nû ya Kurdî li Devera Behdînan da, Zanîngeha Mardin Artuklu, Enstîtuya Zimanên Zindî, Mêrdîn, 2015.

Janez Sar Çeper, Fatime, Lêkolînek li ser Helbesta Qedrî Can, Zanîngeha Mardin Artuklu, Enstîtuya Zimanên Zindî, Mêrdîn, 2014.

Kan, Güneş, Îmaja Ermenî di Romanên Kurdî yên Sovyeta Berê de, Zanîngeha Mardin Artuklu, Enstîtuya Zimanên Zindî, Mêrdîn, 2016.

Karim M.Salih, Hemin, Runbêjîyê di Helbestên Ehmed Muxtar Caf de, Zanîngeha Yüzüncü Y1l, Enstîtuya Zimanên Zindî, Wan, 2016.

Kavşut, Nihat, Ji Hêla Teknîk û Mijarê ve Analîzkirina Romana Şivanê Kurmanca ya Erebê Şemo, Zanîngeha Muş Alparslan, Enstîtuya Zanistên Civakî, Mûş, 2017.

Khamo Khudhur, Shemal, Praktîzekirna Tiyûra Wergirtinê di Edebiyata Olî ya Êzdiyan da, Zanîngeha Mardin Artuklu, Enstîtuya Zimanên Zindî, Mêrdîn, 2016.

Khidhir, Mohammed, Ji bo Zarokan Çîrokên Ajalan (Mînak Çîrokên Kovara Heng 2001-2011), Zanîngeha Yüzüncü Y1l, Enstîtuya Zimanên Zindî, Wan, 2017

Mehemed Kocher, Jasim, Rehendên Derûnî di Hozanên Rojen Barnasî da, Zanîngeha Mardin Artuklu, Enstîtuya Zimanên Zindî, Mêrdîn, 2016.

Mikaeel Azeez Azeez, Saad, Surriyalîzm di Helbesta Nûxazî ya Kurdî de (bi nimûne Helbestên Sebah Rencder), Zanîngeha Bingöl, Enstîtuya Zimanên Zindî, Çewlîg, 2017.

Mohammad Hussein, Hlbeen, Pêkhateyên Diramayê di Hozanên Bedîrxan Sindî da, Zanîngeha Mardin Artuklu, Enstîtuya Zimanên Zindî, Mêrdîn, 2014.

Mohammed Ahmed, Hariwan, Teknîka Dubarekirinê di Avakirina Rîtma Navxweyî ya Helbestên Kamîran Bedirxanî de -Dîwana Dilê Kurên Min wek Nimûne-, Zanîngeha Mardin Artuklu, Enstîtuya Zimanên Zindî, Mêrdîn, 2017.

Mohammed Ghaffar, Nergiz, Îstatîka Cihî di Romanên Sebrî Silêvanî da, Zanîngeha Mardin Artuklu, Enstîtuya Zimanên Zindî, Mêrdîn, 2014.

Mohammed Hussein, Safen, Rehendê Derûnî di Helbestên Ebdula Peşêw de, Zanîngeha Yüzüncü Y1l, Enstîtuya Zimanên Zindî, Wan, 2017.

Mohammed Rashid, Hawkar, Teknîka Vegotinê di Romanê de (Mîrname ya Jan Dost Wek Mînak), Zanîngeha Yüzüncü Y1l, Enstîtuya Zimanên Zindî, Wan, 2016.

Muhammed Mawlud, Qabeel, Rola Rojnama Bizav di Pêşxistina Helbesta Kurdî li Devera Behdînan, Zanîngeha Yüzüncü Y1l, Enstîtuya Zimanên Zindî, Wan, 2017.

Mushir Salih, Tara, Hawwata û Firewata le Pendekanî Pîremêrdî Şaîr, Zanîngeha Mardin Artuklu, Enstîtuya Zimanên Zindî, Mêrdîn, 2016.

Mustafa Hamad, Jamal, Dîroka Wêjeya Kurdî a Merif Xeznedar ̂̂ rol û Taybetmendiyên Wî, Zanîngeha Yüzüncü Y1l, Enstîtuya Zimanên Zindî, Wan, 2017. 
Nori Omer, Salam, Rolê Kovara Metîn di Pêşxistina Vekolînên Edebî de, Zanîngeha Yüzüncü Y1l, Enstîtuya Zimanên Zindî, Wan, 2017.

Omar Ahmed, Honar, Evîn û Hezkirina Jinê di Helbestên Mistefa Begê Kurdî da, Zanîngeha Yüzüncü Y1l, Enstîtuya Zimanên Zindî, Wan, 2017.

Omar Ali, Sarhang, Bingehê Karakter di Romana Hesar û Segên Bavê Min ya Şêrzad Hesen de, Zanîngeha Yüzüncü Y1l, Enstîtuya Zimanên Zindî, Wan, 2016.

Omer Sadiq, Avan, Di Helbestên Goran de Tasîra Rêbazên Pernasîzimê û Sembolîzimê, Zanîngeha Yüzüncü Y1l, Enstîtuya Zimanên Zindî, Wan, 2017.

Orak Reşitoglu, Sevda, Helbestvanên Jin di Edebiyata Yarsanan de, Zanîngeha Mardin Artuklu, Enstîtuya Zimanên Zindî, Mêrdîn, 2016.

Othman Qader, Samad, Zimanê Ragihandinê di Nuçeyên Rojname Elektronîk de, Zanîngeha Yüzüncü Y1l, Enstîtuya Zimanên Zindî, Wan, 2017.

Özcan, Mulazım, Di Salên 1980-2000an de li Tirkîyeyê Rewşa Ziman û Edebiyata Kurdî û Têkiliya Wan li gel Tevgerên Civakî yên Kurdan, Zanîngeha Yüzüncü Yı1, Enstîtuya Zimanên Zindî, Wan, 2018.

Öztürk, İrfan, Hîmên Helbesta Kovara Tîrêjê, Zanîngeha Mardin Artuklu, Enstîtuya Zimanên Zindî, Mêrdîn, 2014.

Pesen, Abdurahim, Helbesta Arjen Arî (Naverok-Şêwe-Binyad), Zanîngeha Bingöl, Enstîtuya Zimanên Zindî, Çewlîg, 2015.

Polat, Edip, Di Çend Pexşanên Kurmancî de Evînên Efsanevî, Zanîngeha Mardin Artuklu, Enstîtuya Zimanên Zindî, Mêrdîn, 2014.

Polat, Leyla, Wekî Kirdeyekê Hebûn û Temsîliyeta Jinan (Awirtêdaneke Rexneyî a Femînîst bo Berhemên Dilawer Zeraq), Zanîngeha Yüzüncü Y1l, Enstîtuya Zimanên Zindî, Wan, 2017.

Rashad Qader, Zeyad, Bi Zaravayê Soranî Helbestên Zarokan li Edebê Kurdî de (Zêwer, Goran, Letîf Helmet û Emîn Mihemed), Zanîngeha Yüzüncü Y1l, Enstîtuya Zimanên Zindî, Wan, 2016.

Rasool Aba Baker Mangurî, Mangoor, Bingeha Wêneyên Hunerî di Helbestên Hêmin de, Zanîngeha Yüzüncü Y1l, Enstîtuya Zimanên Zindî, Wan, 2016.

Rojdar Yıldız, Reşit, Di Edebiyata Zarokan de Çîrok, Zanîngeha Yüzüncü Yı1, Enstîtuya Zimanên Zindî, Wan, 2017.

Safeen Sadi Saadi, Sahand, Rehendên Dîrokî Di Romana "Xewna Zelamên Îranî" Mardîn Îbrahîmê, Zanîngeha Yüzüncü Y1l, Enstîtuya Zimanên Zindî, Wan, 2016.

Sagvan, Omeed, Xwekuştin di Romanên Kovan Sindî de, Zanîngeha Mardin Artuklu, Enstîtuya Zimanên Zindî, Mêrdîn, 2017.

Saiwan Ahmed, Omar, Edebiyatî Enfal le Govare Kurdiyekanî Nawçeyî Germiyan da (1992-2012), Zanîngeha Mardin Artuklu, Enstîtuya Zimanên Zindî, Mêrdîn, 2016.

Saleh Hussein, Nadhim, Kovargeriya Zarokan li Başûrê Kurdistanê (Mînak: Kepir), Zanîngeha Yüzüncü Y1l, Enstîtuya Zimanên Zindî, Wan, 2018.

Salih Shaduman, Omar, Cuwankarî le Şi'rî Hewçerxî Kurdî da, Zanîngeha Bingöl, Enstîtuya Zimanên Zindî, Çewlîg, 2018. 
Siaband Abbas, Reber, Efsane di Grûba Edebî ya Nûkirin Her $\hat{u}$ Her da Hizirvan Ebdulla Wek Nimûne, Zanîngeha Mardin Artuklu, Enstîtuya Zimanên Zindî, Mêrdîn, 2018.

Sulaiman Ismael, Ismael, Rengvedana Zindanê di Romanên Selam 'Ebdulla de, Zanîngeha Mardin Artuklu, Enstîtuya Zimanên Zindî, Mêrdîn, 2018.

Tawfeeq Raof, Nawshirwan, Binyata 'Struktûra Bûyerê di Romana Evara Perwaneyê ya Bextiyar Elî de, Zanîngeha Yüzüncü Y1l, Enstîtuya Zimanên Zindî, Wan, 2016.

Yeşilmen, Davut, Temaya Sirgûnê di Çar Romanên Kurdî (Kurmancî) de, Zanîngeha Mardin Artuklu, Enstîtuya Zimanên Zindî, Mêrdîn, 2014.

Y1lmaz, Ferhat, Berawirdkirinek li ser Şivanê Kurmanca û Sêbareya Maksîm Gorkî, Zanîngeha Mardin Artuklu, Enstîtuya Zimanên Zindî, Mêrdîn, 2015.

Yonat, Mehmet, Kovara Nûdemê û di Kovara Nûdemê de Şopên Surgunê, Zanîngeha Muş Alparslan, Enstîtuya Zanistên Civakî, Mûş, 2015.

\subsection{Edebiyata Zarokan}

Hikmat Ali Zada, Partiman, Rolê Govara Kepir di Pêşxistina Çîroka Zarokan de, Zanîngeha Mardin Artuklu, Enstîtuya Zimanên Zindî, Mêrdîn, 2018.

Khidhir, Mohammed, Ji bo Zarokan Çîrokên Ajalan (Mînak Çîrokên Kovara Heng 2001-2011), Zanîngeha Yüzüncü Y1l, Enstîtuya Zimanên Zindî, Wan, 2017

Saleh Hussein, Nadhim, Kovargeriya Zarokan li Başûrê Kurdistanê (Mînak: Kepir), Zanîngeha Yüzüncü Y1l, Enstîtuya Zimanên Zindî, Wan, 2018.

Tosun, Türkan, Edebiyata Zarokan di Kovara Nûbiharê de (1992-2010), Zanîngeha Bingöl, Enstîtuya Zimanên Zindî, Çewlîg, 2017.

Yıldız, Reşit Rojdar, Di Edebiyata Zarokan de Çîrok, Zanîngeha Yüzüncü Y1l, Enstîtuya Zimanên Zindî, Wan, 2017.

\subsection{Ferhengnasî}

Aygün, Muhsin, Bingöl Yöresinde Kullanılan Zazaca Hayvancılık Kavramları, Zanîngeha Bingöl, Enstîtuya Zimanên Zindî, Çewlîg, 2015.

Başaran, Cahit, Kürt Dilinde Sözlükler, Zanîngeha Bingöl, Enstîtuya Zimanên Zindî, Çewlîg, 2014.

Işık, Ümit, Xebatek li ser Ferhengên Kurdî, Zanîngeha Muş Alparslan, Enstîtuya Zanistên Civakî, Mûş, 2017.

Yılmaz, Abdurrahman, Zazaca-Türkçe Sözlük, Genç-Bingöl Yöresi, Zanîngeha Bingöl, Enstîtuya Zimanên Zindî, Çewlîg, 2015.

\subsection{Folklor}

Ahmed Haji Abozaid, Bayar, Rengvedana Edebê Folklorî di Şiîrên Mela Xelîl Mişextî da, Zanîngeha Mardin Artuklu, Enstîtuya Zimanên Zindî, Mêrdîn, 2018.

Ali Salim, Goran, Rengdana Folklorê di Destana Mem û Zîn ya Ehmedê Xanî da, Zanîngeha Yüzüncü Y1l, Enstîtuya Zimanên Zindî, Wan, 2017.

Apuhan, Danyal, Vistunikunî Zazakiye Çewlig di Bawerî Bêbinî, Zanîngeha Bingöl, Enstîtuya Zimanên Zindî, Çewlîg, 2015. 
Arif, Fakhir Ali, Çavkaniya Jînwarparêzî ya Barzan, Zanîngeha Mardin Artuklu, Enstîtuya Zimanên Zindî, Mêrdîn, 2017.

Asna, Burçin, Bingöl'de Zazaca Atasözlerinin Tahlili, Zanîngeha Bingöl, Enstîtuya Zimanên Zindî, Çewlîg, 2014.

Attı, Hikmettin, Lêkolîneke Folklorî li ser Destana Mem û Zînê, Zanîngeha Mardin Artuklu, Enstîtuya Zimanên Zindî, Mêrdîn, 2013.

Aygün, Muhsin, Bingöl Yöresinde Kullanılan Zazaca Hayvancılık Kavramları, Zanîngeha Bingöl, Enstîtuya Zimanên Zindî, Çewlîg, 2015.

Baiz Rahman, Mohammed, Rola Folklorê di Perwerdekirina Zarokan de Mînak: Çîrok, Zanîngeha Yüzüncü Y1l, Enstîtuya Zimanên Zindî, Wan, 2016.

Başaran, Tahir, Di Vegotinên Devkî de Tîpê Behlûl, Zanîngeha Muş Alparslan, Enstîtuya Zanistên Civakî, Mûş, 2018.

Baykal, Nimet, Çend Çîrokên Kurdî yên Dişibin Çîrokên di Gulistana Sa'dî Şîrazî, Zanîngeha Bingöl, Enstîtuya Zimanên Zindî, Çewlîg, 2017.

Begik, Mahmut, Dengbêj Resoyê Gopala (Jiyan û Berhem), Zanîngeha Mardin Artuklu, Enstîtuya Zimanên Zindî, Mêrdîn, 2013.

Bor, Abdulkerim, Bingöl Yöresi Zazaca Halk Türküleri, Zanîngeha Bingöl, Enstîtuya Zimanên Zindî, Çewlîg, 2014.

Bozkoyun, Mehmet, Çend Çîrokên Herêma Şêxan (Metn-Analîz), Zanîngeha Bingöl, Enstîtuya Zimanên Zindî, Çewlîg, 2015.

Buran, Eşref, Mela Wekî Tîpekî Pêkenokên Kurdî, Zanîngeha Mardin Artuklu, Enstîtuya Zimanên Zindî, Mêrdîn, 2018.

Çalıştıran Karabat, Ruken, Lêkolîneke Giştî li ser Çîrokên Kurdî yên Gelêrî (Bi Nimûneyên di Veşanên Ekola Şamê de) (Vekolîn-Senifandin), Zanîngeha Mardin Artuklu, Enstîtuya Zimanên Zindî, Mêrdîn, 2015.

Çeçen, Ramazan, Di Edebiyata Kurdî de Folklor û Roman li dor Texeyyulên Berê Rêçên Îroyîn, Zanîngeha Mardin Artuklu, Enstîtuya Zimanên Zindî, Mêrdîn, 2013.

Çelik, Murat, 'Adat û Rusûmatname'ê Tewayifê Ekradiye ya Mela Mehmûdê Bazîîi, Zanîngeha Mardin Artuklu, Enstîtuya Zimanên Zindî, Mêrdîn, 2015.

Çeliktaş, Sami, Tîpolojiya Lehengê Kurd li Çarçoveya Nêrînên Joseph Campbell Bi Mînakên Rustemê Zal û Memê Alan-, Zanîngeha Mardin Artuklu, Enstîtuya Zimanên Zindî, Mêrdîn, 2018.

Çiftçi, Tekin, Di Kilamên Evînî yên Dengbêjan de Temaya Jinê, Zanîngeha Mardin Artuklu, Enstîtuya Zimanên Zindî, Mêrdîn, 2012.

Dawood Sherzad, Rebaz, Cedelyeya Jiyan û Mirin di Şi’ra Mahwî da, Zanîngeha Yüzüncü Y1l, Enstîtuya Zimanên Zindî, Wan, 2017.

Demir, Bünyamin, Çîrokên Kurdî li gorî Motîf Îndeksa Stith Thompson (Bi Nimûneyên Çîrokên Mîrze Mihemed), Zanîngeha Mardin Artuklu, Enstîtuya Zimanên Zindî, Mêrdîn, 2016.

Dolgun, Ridvan, Mintiqaya Darahênî-Zikte de Termê Hacetan û Manayanê Hacetanê ke Cuya Rojane de Şuxulyene, Zanîngeha Bingöl, Enstîtuya Zimanên Zindî, Çewlîg, 2015. 
Ece, Emre, Monografiya Çanda Gel a Dêrika Çiyayê Maẑ, Zanîngeha Mardin Artuklu, Enstîtuya Zimanên Zindî, Mêrdîn, 2017.

Ekinci, Muzaffer, Lêkolînek li ser Motîfên Lawiran ên ku di Berhema M. Emîn Bozarslan ya Rêzeçîrokên Lawiran a bi Navê 'Meselokên Lawiran'de Cih Digirin, Zanîngeha Muş Alparslan, Enstîtuya Zanistên Civakî, Mûş, 2016.

Erdoğmuş, Hatip, Meseleyê Dormalê Darahênî (Metne-Tedqîq), Zanîngeha Bingöl, Enstîtuya Zimanên Zindî, Çewlîg, 2015.

Farhad Abdullah, Sardar, Nûjenxazî di Rûxsara Helbestên Şêx Nurî da, Zanîngeha Yüzüncü Y1l, Enstîtuya Zimanên Zindî, Wan, 2017.

Filiz, Mehmet Şirin, Xebatek li ser Destana Dewrêşê Evdî, Zanîngeha Mardin Artuklu, Enstîtuya Zimanên Zindî, Mêrdîn, 2014.

Gökalp, Büşra, Bingöl Masallarında -Seçilmiş Örneklerde- Sembolik Masal Çözümlemeleri, Zanîngeha Bingöl, Enstîtuya Zimanên Zindî, Çewlîg, 2018.

Gören, Ebubekir, Di Romanên Erebê Şemo de Folklora Kurdî, Zanîngeha Mardin Artuklu, Enstîtuya Zimanên Zindî, Mêrdîn, 2013.

Güntaş Aldatmaz, Nadire, Folklorê Kirmancan (Kirdan/Dimiliyan) Ser o Cîgêrayîşê, Zanîngeha Mardin Artuklu, Enstîtuya Zimanên Zindî, Mêrdîn,2013.

Gürsu, Sedat, Bingöl/Kiğı Yöresi Masal Örnekleri ve Tahlili, Zanîngeha Bingöl, Enstîtuya Zimanên Zindî, Çewlîg, 2017.

Gürür, Zeki, Dengbêjî di Peywenda Patronajê de, Zanîngeha Mardin Artuklu, Enstîtuya Zimanên Zindî, Mêrdîn, 2014.

Heider Farhan, Hawkar, Xemilandina Felsefeya Oldariyê di Helbestên Mehwî de, Zanîngeha Yüzüncü Y1l, Enstîtuya Zimanên Zindî, Wan, 2017.

Hussein Ali, Omed, Ciwankarî di Pend û Gotinên Pêşiyan de bi Mînakên "Pendî Pêşînan” a Şêx Mihemedê Xal, Zanîngeha Yüzüncü Y1l, Enstîtuya Zimanên Zindî, Wan, 2017.

İçen, Halil, Di nav Çanda Kurdî de Çîrokek Sîndrella, Zanîngeha Dicle, Enstîtuya Zanistên Civakî, Diyarbekir, 2017.

Jameel Mohammed, Hawkar, Binyadî Gêranewa le Dastanî Mem û Zinî Oskar Mann û Şanoyî Memê Alanî Ebdurehîm Rehmî Hekarî (Lêkolînewekî Berawirdkariyê), Zanîngeha Bingöl, Enstîtuya Zimanên Zindî, Çewlîg, 2017.

Kaplan, Yaşar, Destana Kela Dimdim û Xanê Lepzêrîn: Lêkolînek Edebî û Dîrokî, Zanîngeha Yüzüncü Y1l, Enstîtuya Zimanên Zindî, Wan, 2015.

Khamo Khudhur, Shemal, Praktîzekirna Tiyûra Wergirtinê di Edebiyata Olî ya Êzdiyan da, Zanîngeha Mardin Artuklu, Enstîtuya Zimanên Zindî, Mêrdîn, 2016.

Muhialdien al-Barazanji, Aram, Rengdanên Ola Îslamî ya di Helebestên Nalî de, Zanîngeha Yüzüncü Y1l, Enstîtuya Zimanên Zindî, Wan, 2017.

Naderî Moghadam, Shatav, Şi'rên Şairên Yarsan û Hizrê Yarî, Zanîngeha Yüzüncü Y1, Enstîtuya Zimanên Zindî, Wan, 2016.

Najeb Abdulrazaq, Jegr, Binyatê Honerî di Dastana Zembîlfroş ya Feqiyê Teyran û Miradxanê Bayezîî da, Zanîngeha Mardin Artuklu, Enstîtuya Zimanên Zindî, Mêrdîn, 2017. 
Öner, Ahmet, Di Edebiyata Gelêrî ya Kurdî da Di'a û Nifir, Zanîngeha Yüzüncü Yı1, Enstîtuya Zimanên Zindî, Wan, 2017.

Öztürk, Serdar, Di Tradîsyona Dengbêjiya Kurdî de Şakiro (Jiyan û Berhem), Zanîngeha Mardin Artuklu, Enstîtuya Zimanên Zindî, Mêrdîn, 2014.

Samuk, Hidayet, Servi Bölgesi Folkloru, Zanîngeha Bingöl, Enstîtuya Zimanên Zindî, Çewlîg, 2018.

Samur, Aziz, Destana Zembîlfiroş û Gulxatûnê, Zanîngeha Mardin Artuklu, Enstîtuya Zimanên Zindî, Mêrdîn, 2013.

Saydun, Edip, Teşe û Ciwankariyên Wêjeyî di Dîwana Feqiyê Teyran de, Zanîngeha Yüzüncü Y1l, Enstîtuya Zimanên Zindî, Wan, 2018.

Shirinov, Nofal, Folklora Kurdên Azerbaycanê, Zanîngeha Mardin Artuklu, Enstîtuya Zimanên Zindî, Mêrdîn, 2017.

Shukur Mahmood, Imad, Têgeh û Zaravayê Îrfanî di Helbestên Fexredîn Eraqî û Mihwî de, Zanîngeha Yüzüncü Y1l, Enstîtuya Zimanên Zindî, Wan, 2017.

Siaband Abbas, Reber, Efsane di Grûba Edebî ya Nûkirin Her $\hat{u}$ Her da Hizirvan Ebdulla Wek Nimûne, Zanîngeha Mardin Artuklu, Enstîtuya Zimanên Zindî, Mêrdîn, 2018.

Subaşı, Kenan, Ji bo Zarokan di Fêrkirina Kurdî de Rola Mamikan, Zanîngeha Mardin Artuklu, Enstîtuya Zimanên Zindî, Mêrdîn, 2014.

Taş, Melik, Lêkolînek li ser Çanda Devkî ya Çaldiranê, Zanîngeha Muş Alparslan, Enstîtuya Zanistên Civakî, Mûş, 2018.

Tektaş, İhsan, Mintiqaya Licê ra Diwês Sanikî û Versîyonê Înan: Pêveronayîş û Tehlîl, Zanîngeha Mardin Artuklu, Enstîtuya Zimanên Zindî, Mêrdîn, 2018.

Yeşilçınar, Fehmi, Jiyan û Kilamên Dengbêj Ahmed Alîksan, Zanîngeha Muş Alparslan, Enstîtuya Zanistên Civakî, Mûş, 2015.

Yıldırımçakar, Mehmet, Heyranok di Edebiyata Kurdî ya Gelêrî de Mînaka Herêma Wanê, Zanîngeha Muş Alparslan, Enstîtuya Zanistên Civakî, Mûş, 2017.

Yıldız, Ayhan, Qewlê Hespê Reş, Zanîngeha Mardin Artuklu, Enstîtuya Zimanên Zindî, Mêrdîn, 2015.

Yıldız, Reşit Rojdar, Di Edebiyata Zarokan de Çîrok, Zanîngeha Yüzüncü Yı1, Enstîtuya Zimanên Zindî, Wan, 2017.

Yılmaz, İsa, Vekolînek li ser Çîroka Zembîlfıroş, Zanîngeha Muş Alparslan, Enstîtuya Zanistên Civakî, Mûş, 2016.

\subsection{Jînenîgerî / Biyografî}

Adak, Reşat, Di Serdema Meşrûtiyetê de Zanyarekî Kurd: Seîdê Kurdî û Hizr û Xîtabên Vî Derheqê Hişmendiya Gelê Kurd de, Zanîngeha Mardin Artuklu, Enstîtuya Zimanên Zindî, Mêrdîn, 2013.

Begik, Mahmut, Dengbêj Resoyê Gopala (Jiyan û Berhem), Zanîngeha Mardin Artuklu, Enstîtuya Zimanên Zindî, Mêrdîn, 2013.

Ekici, Abdullah, Zeynelabidînê Amidî: Jiyan Berhem û Xebatên Wî yên Destnivîsî, Zanîngeha Mardin Artuklu, Enstîtuya Zimanên Zindî, Mêrdîn, 2014. 
Öztürk, Serdar, Di Tradîsyona Dengbêjiya Kurdî de Şakiro (Jiyan û Berhem), Zanîngeha Mardin Artuklu, Enstîtuya Zimanên Zindî, Mêrdîn, 2014.

Tanrıkulu, Veysel, Kürtçe Masallar ile Grimm Kardeşler Masallarının Motifler Açısından Karşılaştırılması, Zanîngeha Dicle, Enstîtuya Zanistên Civakî, Diyarbekir, 2017.

Yeşilçınar, Fehmi, Jiyan û Kilamên Dengbêj Ahmed Alîksan, Zanîngeha Muş Alparslan, Enstîtuya Zanistên Civakî, Mûş, 2015.

\subsection{Perwerde}

Baiz Rahman, Mohammed, Rola Folklorê di Perwerdekirina Zarokan de Mînak: Çîrok, Zanîngeha Yüzüncü Y1l, Enstîtuya Zimanên Zindî, Wan, 2016.

Başdaş, Servan, Fonksiyonên Çîrokan di Perwerdehiyê de (Vekolîn-Tekst-Analîz), Zanîngeha Mardin Artuklu, Enstîtuya Zimanên Zindî, Mêrdîn, 2018.

Demiral Taher, İde, Perwerdeya Nirxên Çandî û Civakî di Kovargeriya Zarokan a Kurmancî-Latînî de (1980-2015), Zanîngeha Mardin Artuklu, Enstîtuya Zimanên Zindî, Mêrdîn, 2018.

Geyik, Resul, Hînkirina Kurdî Wekî Zimanê Yekem, Zanîngeha Yüzüncü Y11, Enstîtuya Zimanên Zindî, Wan, 2016.

Karagöz, Naci, Seçmeli Kürtçe Dersine Karşı Veli Tutumları, Zanîngeha Dicle, Enstîtuya Zanistên Civakî, Diyarbekir, 2016.

Kurt, Şehmuz, Nirxandina Pirtûka Hînkirina Kurdî: Hînker -Li gorî Nêrînên Xwendekar ̂̂ Mamosteyan-, Zanîngeha Mardin Artuklu, Enstîtuya Zimanên Zindî, Mêrdîn, 2015.

Subaşı, Kenan, Ji bo Zarokan di Fêrkirina Kurdî de Rola Mamikan, Zanîngeha Mardin Artuklu, Enstîtuya Zimanên Zindî, Mêrdîn, 2014.

Tarduş, Ibrahim, Bikaranîna Çîrokên Kurdî di Perwerdeya Zarokan de, Zanîngeha Mardin Artuklu, Enstîtuya Zimanên Zindî, Mêrdîn, 2015.

Yıldırımçakar, Adil, Bedîuzaman Seîdê Kurdî û Projeya Wî ya Medresetuzehra, Zanîngeha Yüzüncü Y1l, Enstîtuya Zimanên Zindî, Wan, 2016.

\subsection{Wergernasî}

Yıldırımçakar, Ziyattin, Werger wek Kirineke Çandî, li ser Riyên Vergernasiyê ber bi Kurdolojiyê ve, Zanîngeha Mardin Artuklu, Enstîtuya Zimanên Zindî, Mêrdîn, 2016.

\subsection{Zimannasî}

Abdulsetar Abdulkarim, Shamal, Bernav Di Zimanê Kurdî da li Govera Badînan, Zanîngeha Yüzüncü Y1l, Enstîtuya Zimanên Zindî, Wan, 2018.

Abi, Abdulmenaf, Di Kurmanciya Jorîn û Kurmanciya Nawerast de Qertafên Lêkeran, Zanîngeha Yüzüncü Y1l, Enstîtuya Zimanên Zindî, Wan, 2018.

Açar, Zafer, Devoka Devera Filistanê, Zanîngeha Bingöl, Enstîtuya Zimanên Zindî, Çewlîg, 2015.

Ahmed, M. Araz, Berawirdiyek di Navbera Morfîmên Rêzimaniyên Karî di Kurmanciya Bakûr a Stander û Devoka Duhokê da, Zanîngeha Mardin Artuklu, Enstîtuya Zimanên Zindî, Mêrdîn, 2014. 
Ali Salih, Gharib, Berhevxistna Cînavkên Kesî di Kurmanciya Jorîn û Jêrîn de, Zanîngeha Yüzüncü Y1l, Enstîtuya Zimanên Zindî, Wan, 2017.

Aslanoğulları, Mehmet, Lerch'in Zazaki Derlemelerinin Çevrimyazımı ve Türlerine Göre Sözcüklerin Tahlili, Zanîngeha Bingöl, Enstîtuya Zimanên Zindî, Çewlîg, 2014.

Babayiğit, Mehmet Veysi, İngilizce, Kürtçe ve Türkçe'de Zamanların Sentaks (Sözdizimsel) Karşılaştırılması, Zanîngeha Dicle, Enstîtuya Zanistên Civakî, Diyarbekir, 2016.

Balta, Adem, Rê û Rêbazên Nivisîna Nûçeyên Kurdî, Zanîngeha Muş Alparslan, Enstîtuya Zanistên Civakî, Mûş, 2017.

Bingöl, Ibrahim, Kirmanckî (Zazakî) de Pêveronayîşê Fekê Çewlîgî û Gimgimî, Zanîngeha Mardin Artuklu, Enstîtuya Zimanên Zindî, Mêrdîn, 2013.

Çapar, İbrahim, Kürtçe ve İngilizce'de Deyimsel ve Edatlı Fiillerin Karşılaştırılması, Zanîngeha Dicle, Enstîtuya Zanistên Civakî, Diyarbekir, 2017.

Delikaya, Ömer, Peyvsazî di Kurmancî de: Nêrîneke Giştî, Zanîngeha Bingöl, Enstîtuya Zimanên Zindî, Çewlîg, 2016.

Demir, Perihan, Zazakî de Derheqê̂ Awanî û Antişî yê Karî Ser Yew Cigêrayîş, Zanîngeha Bingöl, Enstîtuya Zimanên Zindî, Çewlîg, 2015.

Ersoy, Turgut, Veracêkerdana Gramerê Zazakî û Kirmancî: Diyalekt Alfabe û Fonetîk Morfolojî, Zanîngeha Mardin Artuklu, Enstîtuya Zimanên Zindî, Mêrdîn, 2014.

Gemsiz, Mehmet, Binyat û Rastnivîsîna Lêkeran di Berhemên Rêzimanê yên Kurmancîya Bakur de, Zanîngeha Mardin Artuklu, Enstîtuya Zimanên Zindî, Mêrdîn, 2018.

Güneri, Ahmet, Nomînal Morfolojiya Kurmanciya Herêma Torê, Zanîngeha Mardin Artuklu, Enstîtuya Zimanên Zindî, Mêrdîn, 2018.

Güneş, Cemil, Pirsgirêkên Zarokên Duziman di Dibistanên Yekziman de, Zanîngeha Mardin Artuklu, Enstîtuya Zimanên Zindî, Mêrdîn, 2018.

Güzel, Şerif, Lêkolînek Sentaksî li ser Berhema Camî'eya Rîsaleyan û Hîkayetan, Zanîngeha Muş Alparslan, Enstîtuya Zanistên Civakî, Mûş, 2018.

Hama Murad Majid, Edris, Destpêkêk je bo Nasandina Zanesta Ziman, Zanîngeha Yüzüncü Y1l, Enstîtuya Zimanên Zindî, Wan, 2017.

Işık, Ümit, Xebatek li ser Ferhengên Kurdî, Zanîngeha Muş Alparslan, Enstîtuya Zanistên Civakî, Mûş, 2017.

Jabar Abozaid, Majid, Rolê Morfemên Nivşî di Sentaksa Zimanê Kurdî de (Govera Behdînî), Zanîngeha Mardin Artuklu, Enstîtuya Zimanên Zindî, Mêrdîn, 2018.

Jafarzadeh, Mehdi, Analîza Kurmanciya Deregeza Xorasanê li gor Hêmanên Zimannasiyê, Zanîngeha Mardin Artuklu, Enstîtuya Zimanên Zindî, Mêrdîn, 2017.

Jamal Ahmad, Azhin, Raçavkirina Aliyên Derunî di Karên Darêjî di Zimanê Kurdî de, Zanîngeha Yüzüncü Y1l, Enstîtuya Zimanên Zindî, Wan, 2017.

Kaçan, Muhammed Emin, Zazakî de Kategorîzekerdişê Edatan û Metnanê Zazakî ra Nimûneyî, Zanîngeha Mardin Artuklu, Enstîtuya Zimanên Zindî, Mêrdîn, 2018. 
Kamal Yousif, Hajar, Vata di Diyaloga Karîkatêrê Kurdî da (Vekolîneka Sîmantîkî û Pragmatîkiye), Zanîngeha Mardin Artuklu, Enstîtuya Zimanên Zindî, Mêrdîn, 2014.

Kanabi Taher, Barzan, Bas û Xwas Le Manşetî Hewal Rojnamekanî Xebat, Kurdistanî Nûwe û Rojname: Be Numûne Lêkolîneweyekî Simantîkî û Pragmatîkî, Zanîngeha Bingöl, Enstîtuya Zimanên Zindî, Çewlîg, 2018.

Karabayeser, Ayetullah, Zazakî di Wexti, Zanîngeha Bingöl, Enstîtuya Zimanên Zindî, Çewlîg, 2017.

Kılıç, Özlem, Gramerê Zazakî de Derheqê Negatîfîye Yew Cigêrayîş, Zanîngeha Bingöl, Enstîtuya Zimanên Zindî, Çewlîg, 2015.

Laçin, Şahap, Zazakî de Zerfî û Goreyê Raweyan Şuxulnayîşê Zerfan, Zanîngeha Bingöl, Enstîtuya Zimanên Zindî, Çewlîg, 2018.

Mohammed Abdolqader, Shivan, Rola Gîreyan di Polguherîna Peyvê de di Kurmanciya Serî Devoka Behdînan da, Zanîngeha Mardin Artuklu, Enstîtuya Zimanên Zindî, Mêrdîn, 2016.

Mushir Salih, Tara, Hawwata û Firewata le Pendekanî Pîremêrdî Şaîr, Zanîngeha Mardin Artuklu, Enstîtuya Zimanên Zindî, Mêrdîn, 2016.

Nawzad Faqe Ibrahim, Hana, Gireke Rêzimanî û Ferhengiyekanî Kar le Zimanî Kurdî û Farisî da, Zanîngeha Bingöl, Enstîtuya Zimanên Zindî, Çewlîg, 2017.

Omar Mahmoud, Barzo, Şîrovekirineke Dengsazî û Fonolojî di Kurdiya Kurmancî de, Zanîngeha Mardin Artuklu, Enstîtuya Zimanên Zindî, Mêrdîn, 2016.

Öçal, Serdar, Awayê Lêkirina Navan li Herêma Dêrîkê (Lêkolîneke OnomastîkSosyolojîk), Zanîngeha Mardin Artuklu, Enstîtuya Zimanên Zindî, Mêrdîn, 2016.

Sayım, İlyas, Kurmancî ve Hintçede Ergatif Yapı Üzerine Bir İnceleme, Zanîngeha Muş Alparslan, Enstîtuya Zanistên Civakî, Mûş, 2017.

Söylemez, Semra, Melekan, Gaz ve Muradan Köyleri Zazacasının Ses Değişimi Yönünden Karşilaştırılması, Zanîngeha Bingöl, Enstîtuya Zimanên Zindî, Çewlîg, 2014.

Şanl1, Esat, Têvernayîşê Kurmancî û Zazakî: Nimuneyê Licê û Hezanê, Zanîngeha Mardin Artuklu, Enstîtuya Zimanên Zindî, Mêrdîn, 2017.

Taher Bazid, Berqee, Hevalnav di Navbera Zimanê Kurdî (Kurmanciya Serî) û Tirkî da, Zanîngeha Mardin Artuklu, Enstîtuya Zimanên Zindî, Mêrdîn, 2017.

Taman, Bahattin, Daçek di Zaravayê Kurmancî da, Zanîngeha Mardin Artuklu, Enstîtuya Zimanên Zindî, Mêrdîn, 2018.

Taş, Çetin, Dengsaziya Devoka Çaldiranê, Zanîngeha Mardin Artuklu, Enstîtuya Zimanên Zindî, Mêrdîn, 2015.

Tunç, Vehbi, Gılgamış Destanı'nda Sümerce ile Kürtçe'nin Sosyo-linguistik Bağlantısı, Zanîngeha Dicle, Enstîtuya Zanistên Civakî, Diyarbekir, 2016.

Veroj, Sait, Veracêkerdena Gramerê Zazakî û Kurmancî: Dîyalekt, Alfabe û Fonetîk, Morfolojî, Zanîngeha Mardin Artuklu, Enstîtuya Zimanên Zindî, Mêrdîn, 2014.

Yaman, Raif, Fonemên Kurdî yên Kurdzan û Gerokên Ewrûpî û Amerîkî (17871887), Zanîngeha Mardin Artuklu, Enstîtuya Zimanên Zindî, Mêrdîn, 2016. 
Yıldız, Pınar, Mehelî û Kirmanckîya Înan, Zanîngeha Mardin Artuklu, Enstîtuya Zimanên Zindî, Mêrdîn, 2016.

Yıldızhan, Veysel, Bi Tarîxê Nusîyanena Xo ya Tewr Kehene Çekuyê Kirmanckî (Zazakî) (1798-1903), Zanîngeha Mardin Artuklu, Enstîtuya Zimanên Zindî, Mêrdîn, 2017.

\section{Lîsteya Alfabetîk}

Abdulhaleq Salahaldin, Barzi, Wêneya Helbestî di Helbestên Kurdî yên Mistefa Begê Kurdî da, Zanîngeha Yüzüncü Y1l, Enstîtuya Zimanên Zindî, Wan, 2017.

Abdullah Khudhur, Nali, Rexneya Civakî Di Helbestên Abdullah Paşêw de, Zanîngeha Yüzüncü Y1l, Enstîtuya Zimanên Zindî, Wan, 2016.

Abdulsetar Abdulkarim, Shamal, Bernav Di Zimanê Kurdî da li Govera Badînan, Zanîngeha Yüzüncü Y1l, Enstîtuya Zimanên Zindî, Wan, 2018.

Abi, Abdulmenaf, Di Kurmanciya Jorîn û Kurmanciya Nawerast de Qertafên Lêkeran, Zanîngeha Yüzüncü Y1l, Enstîtuya Zimanên Zindî, Wan, 2018.

Açar, Zafer, Devoka Devera Filistanê, Zanîngeha Bingöl, Enstîtuya Zimanên Zindî, Çewlîg, 2015.

Acun, Roger, Îmaj di Helbesta Kurdî ya Nû ya Bakur de, Zanîngeha Mardin Artuklu, Enstîtuya Zimanên Zindî, Mêrdîn, 2016.

Adak, Reşat, Di Serdema Meşrûtiyetê de Zanyarekî Kurd: Seîdê Kurdî û Hizr û Xîtabên Vî Derheqê Hişmendiya Gelê Kurd de, Zanîngeha Mardin Artuklu, Enstîtuya Zimanên Zindî, Mêrdîn, 2013.

Adsay, Fahriye, Romana Kurdî (Kurmancî) ya Dîrokî: Bîra Civakî û Nasname, Zanîngeha Mardin Artuklu, Enstîtuya Zimanên Zindî, Mêrdîn, 2013.

Ahmed Haji Abozaid, Bayar, Rengvedana Edebê Folklorî di Şiîrên Mela Xelîl Mişextî da, Zanîngeha Mardin Artuklu, Enstîtuya Zimanên Zindî, Mêrdîn, 2018.

Ahmed Mohammed, Arshad, Wataya Lawekî di Zimanê Romana Miryema da ya Sebrî Silêvanî, Zanîngeha Mardin Artuklu, Enstîtuya Zimanên Zindî, Mêrdîn, 2018.

Ahmed, M. Araz, Berawirdiyek di Navbera Morfîmên Rêzimaniyên Karî di Kurmanciya Bakûr a Stander û Devoka Duhokê da, Zanîngeha Mardin Artuklu, Enstîtuya Zimanên Zindî, Mêrdîn, 2014.

Akboğa, Hasan, Xelîfe Yûsif û Teqrîza Wî (Metn û Lêkolîn), Zanîngeha Bingöl, Enstîtuya Zimanên Zindî, Çewlîg, 2017.

Akın, Erkan, Mela Ehmedê Cizîrî’nin Gazellerinde Kullanılan Edebi Sanatlar, Zanîngeha Muş Alparslan, Enstîtuya Zanistên Civakî, Mûş, 2017.

Ali Arif, Fakhir, Çavkaniya Jînwarparêzî ya Barzan, Zanîngeha Mardin Artuklu, Enstîtuya Zimanên Zindî, Mêrdîn, 2017.

Ali Mahmood, Yaseen, Xerîbî li Helbestên Hêmîn û Seyyab, Zanîngeha Yüzüncü Yı1, Enstîtuya Zimanên Zindî, Wan, 2017.

Ali Mohammed, Ghalib, Rola Yusufî di Çapemeniya Kurdî de, Zanîngeha Yüzüncü Y1, Enstîtuya Zimanên Zindî, Wan, 2017.

Ali Salih, Gharib, Berhevxistna Cînavkên Kesî di Kurmanciya Jorîn û Jêrîn de, Zanîngeha Yüzüncü Y1l, Enstîtuya Zimanên Zindî, Wan, 2017. 
Ali Salim, Goran, Rengdana Folklorê di Destana Mem û Zîn ya Ehmedê Xanî da, Zanîngeha Yüzüncü Y1l, Enstîtuya Zimanên Zindî, Wan, 2017.

Altınkılıç, Ümran, Xwendineke Baxtînyen di Sê Romanên Kurdî de, Zanîngeha Mardin Artuklu, Enstîtuya Zimanên Zindî, Mêrdîn, 2015.

Anuk, Nevzat, Behsê Tirkkerdişê Kurdan de Merkezêk: Enstîtuyê Cigerayîşê Kulturê Tirk, Zanîngeha Mardin Artuklu, Enstîtuya Zimanên Zindî, Mêrdîn, 2015.

Apuhan, Danyal, Vistunikunî Zazakiye Çewlig di Bawerî Bêbinî, Zanîngeha Bingöl, Enstîtuya Zimanên Zindî, Çewlîg, 2015.

Arif, Fakhir Ali, Çavkaniya Jînwarparêzî ya Barzan, Zanîngeha Mardin Artuklu, Enstîtuya Zimanên Zindî, Mêrdîn, 2017.

Arslan, Mesut, Di Dewra Osmaniyan de Veşangeriya Kitêbên Kurdî (1844-1923), Zanîngeha Mardin Artuklu, Enstîtuya Zimanên Zindî, Mêrdîn, 2014.

Aslanoğulları, Mehmet, Lerch'in Zazaki Derlemelerinin Çevrimyazımı ve Türlerine Göre Sözcüklerin Tahlili, Zanîngeha Bingöl, Enstîtuya Zimanên Zindî, Çewlîg, 2014.

Asna, Burçin, Bingöl'de Zazaca Atasözlerinin Tahlili, Zanîngeha Bingöl, Enstîtuya Zimanên Zindî, Çewlîg, 2014.

Atlı, Zafer, Zeynelabidîn Zinar: Jiyan, Berhem û Senifandina Xebatên Wî, Zanîngeha Bingöl, Enstîtuya Zimanên Zindî, Çewlîg, 2018.

Att1, Hikmettin, Lêkolîneke Folklorî li ser Destana Mem û Zînê, Zanîngeha Mardin Artuklu, Enstîtuya Zimanên Zindî, Mêrdîn, 2013.

Awla Rasul, Luqiman, Ciwankariya Peyvan di Helbestên Kurdî yên Salim de, Zanîngeha Yüzüncü Y1l, Enstîtuya Zimanên Zindî, Wan, 2017.

Aydoğdu, Yusuf, Modern Zaza Hikâyeciliği, Zanîngeha Bingöl, Enstîtuya Zimanên Zindî, Çewlîg, 2015.

Aygün, Muhsin, Bingöl Yöresinde Kullanılan Zazaca Hayvancılık Kavramları, Zanîngeha Bingöl, Enstîtuya Zimanên Zindî, Çewlîg, 2015.

Aykaç, Seyfettin, Mela Mehmûdê Tîruwayî û Ferhenga Wî ya Menzûm (Metn û Lêkolîn), Zanîngeha Bingöl, Enstîtuya Zimanên Zindî, Çewlîg, 2016.

Aykaç, Yakup, Dîwana Hexîn (Metn, Lêkolîn û Ferheng), Zanîngeha Bingöl, Enstîtuya Zimanên Zindî, Çewlîg, 2015.

Babayiğit, Mehmet Veysi, İngilizce, Kürtçe ve Türkçe'de Zamanların Sentaks (Sözdizimsel) Karşılaştırılması, Zanîngeha Dicle, Enstîtuya Zanistên Civakî, Diyarbekir, 2016.

Baiz Rahman, Mohammed, Rola Folklorê di Perwerdekirina Zarokan de Mînak: Çîrok, Zanîngeha Yüzüncü Y1l, Enstîtuya Zimanên Zindî, Wan, 2016.

Bakırhan, Cihat, Mele Nurullahê Godîşîi'nin 'Çenta Yetîman' Adlı Eserinin Transkripsiyonu, Türkçeye Çevirisi, Tahlil ve Tenkidi, Zanîngeha Muş Alparslan, Enstîtuya Zanistên Civakî, Mûş, 2017.

Balta, Adem, Rê û Rêbazên Nivisîna Nûçeyên Kurdî, Zanîngeha Muş Alparslan, Enstîtuya Zanistên Civakî, Mûş, 2017.

Başaran, Cahit, Kürt Dilinde Sözlükler, Zanîngeha Bingöl, Enstîtuya Zimanên Zindî, Çewlîg, 2014. 
Başaran, Tahir, Di Vegotinên Devkî de Tîpê Behlûl, Zanîngeha Muş Alparslan, Enstîtuya Zanistên Civakî, Mûş, 2018.

Başdaş, Servan, Fonksiyonên Çîrokan di Perwerdehiyê de (Vekolîn-Tekst-Analîz), Zanîngeha Mardin Artuklu, Enstîtuya Zimanên Zindî, Mêrdîn, 2018.

Baykal, Nimet, Çend Çîrokên Kurdî yên Dişibin Çîrokên di Gulistana Sa'dî Şîrazî, Zanîngeha Bingöl, Enstîtuya Zimanên Zindî, Çewlîg, 2017.

Begik, Mahmut, Dengbêj Resoyê Gopala (Jiyan û Berhem), Zanîngeha Mardin Artuklu, Enstîtuya Zimanên Zindî, Mêrdîn, 2013.

Beyter, Önder, Dîwana Mela Ehmedê Heyderî (Metn û Lêkolîn), Zanîngeha Mardin Artuklu, Enstîtuya Zimanên Zindî, Mêrdîn, 2013.

Bilge, Evin, Ji Hêla Naverokê ve Dahûrîna Çîrokên Mela Mehmûdê Baẑdî, Zanîngeha Mardin Artuklu, Enstîtuya Zimanên Zindî, Mêrdîn, 2013.

Bingöl, Ibrahim, Kirmanckî (Zazakî) de Pêveronayîșê Fekê Çewlîgî û Gimgimî, Zanîngeha Mardin Artuklu, Enstîtuya Zimanên Zindî, Mêrdîn, 2013.

Bor, Abdulkerim, Bingöl Yöresi Zazaca Halk Türküleri, Zanîngeha Bingöl, Enstîtuya Zimanên Zindî, Çewlîg, 2014.

Bozkoyun, Mehmet, Çend Çîrokên Herêma Şêxan (Metn-Analîz), Zanîngeha Bingöl, Enstîtuya Zimanên Zindî, Çewlîg, 2015.

Bülbül, Mikail, Di Helbestên Cegerxwîn de Rengvedanên Têkiliyên Îqtîdarî, Zanîngeha Mardin Artuklu, Enstîtuya Zimanên Zindî, Mêrdîn, 2013.

Buran, Eşref, Mela Wekî Tîpekî Pêkenokên Kurdî, Zanîngeha Mardin Artuklu, Enstîtuya Zimanên Zindî, Mêrdîn, 2018.

Çalıştıran Karabat, Ruken, Lêkolîneke Giştî li ser Çîrokên Kurdî yên Gelêrî (Bi Nimûneyên di Veşanên Ekola Şamê de) (Vekolîn-Senifandin), Zanîngeha Mardin Artuklu, Enstîtuya Zimanên Zindî, Mêrdîn, 2015.

Can, Mutlu, Bîblîyografyaya Kirmanckî (Zazakî) (1963-2017), Zanîngeha Mardin Artuklu, Enstîtuya Zimanên Zindî, Mêrdîn, 2018.

Çapar, İbrahim, Kürtçe ve İngilizce'de Deyimsel ve Edatlı Fiillerin Karşılaştırılması, Zanîngeha Dicle, Enstîtuya Zanistên Civakî, Diyarbekir, 2017.

Çeçen, Ramazan, Di Edebiyata Kurdî de Folklor û Roman li dor Texeyyulên Berê Rêçên Îroyîn, Zanîngeha Mardin Artuklu, Enstîtuya Zimanên Zindî, Mêrdîn, 2013.

Çeliktaş, Sami, Tîpolojiya Lehengê Kurd li Çarçoveya Nêrînên Joseph Campbell Bi Mînakên Rustemê Zal û Memê Alan-, Zanîngeha Mardin Artuklu, Enstîtuya Zimanên Zindî, Mêrdîn, 2018.

Çetin, Süleyman, Kovara Hawarê û Bandora Wê ya li ser Zimanê Kurdî, Zanîngeha Yüzüncü Y1l, Enstîtuya Zimanên Zindî, Wan, 2016.

Çiftçi, Metin, Eqîdenameyo Zazakî yê Mehemedê Hezanîyî (Metno Transkrîbekerde, Wekentiş û Açarnayîş), Zanîngeha Bingöl, Enstîtuya Zimanên Zindî, Çewlîg, 2015.

Çiftçi, Tekin, Di Kilamên Evînî yên Dengbêjan de Temaya Jinê, Zanîngeha Mardin Artuklu, Enstîtuya Zimanên Zindî, Mêrdîn, 2012. 
Çoban, Betül, Şopên Realîzma Sosyalist di Romanên Kurdî yên Sovyeta Berê de (1935-1991), Zanîngeha Mardin Artuklu, Enstîtuya Zimanên Zindî, Mêrdîn, 2017.

Dağılma, İbrahim, Mewlîdê Xasî û Hetê Me'na ra Wekentişê Mewlîdî, Zanîngeha Bingöl, Enstîtuya Zimanên Zindî, Çewlîg, 2017.

Dawood Fattah, Diler, Saloxdan di Mîrnameya Jan Dostî de, Zanîngeha Mardin Artuklu, Enstîtuya Zimanên Zindî, Mêrdîn, 2017.

Dawood Sherzad, Rebaz, Cedelyeya Jiyan û Mirin di Şi’ra Mahwî da, Zanîngeha Yüzüncü Y1l, Enstîtuya Zimanên Zindî, Wan, 2017.

Delikaya, Ömer, Peyvsazî di Kurmancî de: Nêrîneke Giştî, Zanîngeha Bingöl, Enstîtuya Zimanên Zindî, Çewlîg, 2016.

Delshad Saleh, Warin, Bekir Begê Erizî (Jiyan û Berhem), Zanîngeha Mardin Artuklu, Enstîtuya Zimanên Zindî, Mêrdîn, 2015.

Demir, Bünyamin, Çîrokên Kurdî li gorî Motîf Îndeksa Stith Thompson (Bi Nimûneyên Çîrokên Mîrze Mihemed), Zanîngeha Mardin Artuklu, Enstîtuya Zimanên Zindî, Mêrdîn, 2016.

Demir, Perihan, Zazakî de Derheqê Awanî û Antişî yê Karî Ser Yew Cigêrayîş, Zanîngeha Bingöl, Enstîtuya Zimanên Zindî, Çewlîg, 2015.

Demiral Taher, İde, Perwerdeya Nirxên Çandî û Civakî di Kovargeriya Zarokan a Kurmancî-Latînî de (1980-2015), Zanîngeha Mardin Artuklu, Enstîtuya Zimanên Zindî, Mêrdîn, 2018.

Deniz, Muhammed İkbal, Jiyana Seyîd 'Eliyê Findikî û Dîwana Wî, Zanîngeha Bingöl, Enstîtuya Zimanên Zindî, Çewlîg, 2017.

Doğan, Songül, Bi Rêbaza Rexneya Femînîst Lênerînek li Romanên Jinên Kurd, Zanîngeha Mardin Artuklu, Enstîtuya Zimanên Zindî, Mêrdîn, 2018.

Döğer, Dilaver, Bêjara Neteweparêz di Kovara Hawarê de, Zanîngeha Yüzüncü Y11, Enstîtuya Zimanên Zindî, Wan, 2017.

Dolgun, Ridvan, Mintiqaya Darahênî-Zikte de Termê Hacetan û Manayanê Hacetanê ke Cuya Rojane de Şuxulyene, Zanîngeha Bingöl, Enstîtuya Zimanên Zindî, Çewlîg, 2015.

Ece, Emre, Monografiya Çanda Gel a Dêrika Çiyayê Mazî, Zanîngeha Mardin Artuklu, Enstîtuya Zimanên Zindî, Mêrdîn, 2017.

Ekici, Abdullah, Zeynelabidînê Amidî: Jiyan Berhem û Xebatên Wî yên Destnivîsî, Zanîngeha Mardin Artuklu, Enstîtuya Zimanên Zindî, Mêrdîn, 2014.

Ekinci, Muzaffer, Lêkolînek li ser Motîfên Lawiran ên ku di Berhema M. Emîn Bozarslan ya Rêzeçîrokên Lawiran a bi Navê 'Meselokên Lawiran'de Cih Digirin, Zanîngeha Muş Alparslan, Enstîtuya Zanistên Civakî, Mûş, 2016.

Eminoğlu, Nevzat, Nêrînek Gelemperî li Mîrektiya Hîzanê: Îlm û Edebiyat, Zanîngeha Mardin Artuklu, Enstîtuya Zimanên Zindî, Mêrdîn, 2016.

Erdoğmuş, Hatip, Meseleyê Dormalê Darahênî (Metne-Tedqîq), Zanîngeha Bingöl, Enstîtuya Zimanên Zindî, Çewlîg, 2015.

Ergün, Zülküf, Di Peydabûna Edebiyata Kurdî ya li Cizîra Botan de Karîgeriya Bajarvaniyê, Zanîngeha Mardin Artuklu, Enstîtuya Zimanên Zindî, Mêrdîn, 2012. 
Ersoy, Turgut, Veracêkerdana Gramerê Zazakî û Kirmancî: Diyalekt Alfabe û Fonetîk Morfolojî, Zanîngeha Mardin Artuklu, Enstîtuya Zimanên Zindî, Mêrdîn, 2014.

Ertekin, Nurettin, Tesewif di Dîwana Şeyda de, Zanîngeha Bingöl, Enstîtuya Zimanên Zindî, Çewlîg, 2018.

Eyer, Ahmet, Kurdên Merwanî di Tarîxu'l-Meyafarqîn a Îbnu'l-Ezraq de, Zanîngeha Mardin Artuklu, Enstîtuya Zimanên Zindî, Mêrdîn, 2016.

Fahmi Farho, Karokh, Bingehê Vegotinê di romana 'Grêweya Bextê Helale'ya Eta Nehayî de, Zanîngeha Yüzüncü Y1l, Enstîtuya Zimanên Zindî, Wan, 2017.

Farhad Abdullah, Sardar, Nûjenxazî di Rûxsara Helbestên Şêx Nurî da, Zanîngeha Yüzüncü Y1l, Enstîtuya Zimanên Zindî, Wan, 2017.

Filiz, Mehmet Şirin, Xebatek li ser Destana Dewrêşê Evdî, Zanîngeha Mardin Artuklu, Enstîtuya Zimanên Zindî, Mêrdîn, 2014.

Gemsiz, Mehmet, Binyat û Rastnivîsîna Lêkeran di Berhemên Rêzimanê yên Kurmancîya Bakur de, Zanîngeha Mardin Artuklu, Enstîtuya Zimanên Zindî, Mêrdîn, 2018.

Geyik, Resul, Hînkirina Kurdî Wekî Zimanê Yekem, Zanîngeha Yüzüncü Y1l, Enstîtuya Zimanên Zindî, Wan, 2016.

Gezer, Semih, Dîwana Mela Yasîn Yusrî (Metn û Lêkolîn), Zanîngeha Bingöl, Enstîtuya Zimanên Zindî, Çewlîg, 2015.

Gider, Ahmet, Molla Muhammed Kavarî Dîvânı'nda Din ve Tasavvuf, Zanîngeha Bingöl, Enstîtuya Zimanên Zindî, Çewlîg, 2017.

Gökalp, Büşra, Bingöl Masallarında -Seçilmiş Örneklerde- Sembolik Masal Çözüimlemeleri, Zanîngeha Bingöl, Enstîtuya Zimanên Zindî, Çewlîg, 2018.

Gören, Ebubekir, Di Romanên Erebê Şemo de Folklora Kurdî, Zanîngeha Mardin Artuklu, Enstîtuya Zimanên Zindî, Mêrdîn, 2013.

Gözeten, İbrahim, Mele Xelîlê Sêrtî û Berhema Wi ya Newcû'l-Enam, Zanîngeha Muş Alparslan, Enstîtuya Zanistên Civakî, Mûş, 2015.

Güneri, Ahmet, Nomînal Morfolojiya Kurmanciya Herêma Torê, Zanîngeha Mardin Artuklu, Enstîtuya Zimanên Zindî, Mêrdîn, 2018.

Güneş, Cemil, Pirsgirêkên Zarokên Duziman di Dibistanên Yekziman de, Zanîngeha Mardin Artuklu, Enstîtuya Zimanên Zindî, Mêrdîn, 2018.

Güntaş Aldatmaz, Nadire, Folklorê Kirmancan (Kirdan/Dimiliyan) Ser o Cîgêrayîşê, Zanîngeha Mardin Artuklu, Enstîtuya Zimanên Zindî, Mêrdîn,2013.

Gürsu, Sedat, Bingöl/Kiğı Yöresi Masal Örnekleri ve Tahlili, Zanîngeha Bingöl, Enstîtuya Zimanên Zindî, Çewlîg, 2017.

Gürür, Zeki, Dengbêjî di Peywenda Patronajê de, Zanîngeha Mardin Artuklu, Enstîtuya Zimanên Zindî, Mêrdîn, 2014.

Güzel, Şerif, Lêkolînek Sentaksî li ser Berhema Camî'eya Rîsaleyan û Hîkayetan, Zanîngeha Muş Alparslan, Enstîtuya Zanistên Civakî, Mûş, 2018.

Haji Sulaiman, Hareem, Hozanetî di Hozanên Sebirî Botanî da, Zanîngeha Yüzüncü Y1l, Enstîtuya Zimanên Zindî, Wan, 2017. 
Hama Murad Majid, Edris, Destpêkêk je bo Nasandina Zanesta Ziman, Zanîngeha Yüzüncü Y1l, Enstîtuya Zimanên Zindî, Wan, 2017.

Hassan Mawlood al-Bajalan, Hardi, Di Helbestên Hemîn Mukiryanî de Civaknasî, Zanîngeha Yüzüncü Y1l, Enstîtuya Zimanên Zindî, Wan, 2017.

Hawkar Jameel, Mohammed, Binyadî Gêranewa le Dastanî Mem û Zinî Oskar Mann û Şanoyî Memê Alanî Ebdurehîm Rehmî Hekarî (Lêkolînewekî Berawirdkariyê), Zanîngeha Bingöl, Enstîtuya Zimanên Zindî, Çewlîg, 2017.

Heider Farhan, Hawkar, Xemilandina Felsefeya Oldariyê di Helbestên Mehwî de, Zanîngeha Yüzüncü Y1l, Enstîtuya Zimanên Zindî, Wan, 2017.

Hesan Kareem, Keywan, Eşq li cem Nalî, Zanîngeha Yüzüncü Y1l, Enstîtuya Zimanên Zindî, Wan, 2017.

Hikmat Ali Zada, Partiman, Rolê Govara Kepir di Pêşxistina Çîroka Zarokan de, Zanîngeha Mardin Artuklu, Enstîtuya Zimanên Zindî, Mêrdîn, 2018.

Hussain, Hunar M., Rollî Rageyandin le Nêzîkkirdnewey Diyalêkte Kurdyekan, Torî Mîdyayî Rudawû be Nimûne, Zanîngeha Mardin Artuklu, Enstîtuya Zimanên Zindî, Mêrdîn, 2015.

Hussein Abo, Reber, Çîroka Gelek Kurt di Edebê Kurdî da li Başûrê Kurdistanê (1991-2013), Zanîngeha Mardin Artuklu, Enstîtuya Zimanên Zindî, Mêrdîn, 2015.

Hussein Ali, Omed, Ciwankarî di Pend û Gotinên Pêşiyan de bi Mînakên "Pendî Pêşînan" a Şêx Mihemedê Xal, Zanîngeha Yüzüncü Y1l, Enstîtuya Zimanên Zindî, Wan, 2017.

Ibrahim Awla, Farman, Di Edebiyata Kurdî ya Kevin û Nû da Erkên Rexneyî, Zanîngeha Yüzüncü Y1l, Enstîtuya Zimanên Zindî, Wan, 2017.

Ibrahim Hami Kocher, Bangeen, Rexneya Civakî di Romanên Hesenê Metê da, Zanîngeha Mardin Artuklu, Enstîtuya Zimanên Zindî, Mêrdîn, 2014.

Ibrahim, Ibrahim, Rengvedana Dîroka Kurdî di Helbestên Cegerxwîn de, Zanîngeha Mardin Artuklu, Enstîtuya Zimanên Zindî, Mêrdîn, 2016.

İçen, Halil, Di nav Çanda Kurdî de Çîrokek Sîndrella, Zanîngeha Dicle, Enstîtuya Zanistên Civakî, Diyarbekir, 2017.

İlhan, Ziver, Mewlûda Mela Huseynê Bateyî (Metn û Lêkolîn), Zanîngeha Mardin Artuklu, Enstîtuya Zimanên Zindî, Mêrdîn, 2013.

Işık, Burhan, Berhema Mehmed Uzun a Binavê Hawara Dîcleyê de Jiyana Kurdan a Civakî, Zanîngeha Muş Alparslan, Enstîtuya Zanistên Civakî, Mûş, 2015.

Işık, Ümit, Xebatek li ser Ferhengên Kurdî, Zanîngeha Muş Alparslan, Enstîtuya Zanistên Civakî, Mûş, 2017.

Ismael Ahmed, Rabar, Teknîk di Deqên Şanoyên Tele’t Saman di Salên Heştêyan de, Zanîngeha Yüzüncü Y1l, Enstîtuya Zimanên Zindî, Wan, 2017.

Ismael Ahmed, Reband, Avahiya Derûnî ya Karekter di Romana Diwahemîn Henarî Dunya yê Bextiyar Elî de, Zanîngeha Yüzüncü Y1l, Enstîtuya Zimanên Zindî, Wan, 2017. 
Ismael Ali, Saman, Vebêjin di Navbera Romana "Navê Min Sor e" ya Orhan Pamuk û "Mîrnameya" Can Dost e, Zanîngeha Yüzüncü Y1l, Enstîtuya Zimanên Zindî, Wan, 2017.

Ismael Khalid Zebari, Rabeea, Lêkolînek li ser Rexne ya Edebî (Kovara Peyv Weke Nûmûne), Zanîngeha Yüzüncü Y1l, Enstîtuya Zimanên Zindî, Wan, 2017.

Issa Ibrahim, Hayhat, Xweza di Helbestên Nû yên Kurdî de Helbestên Qadir Qeçax û Edîb Çelkî wek Nimûne, Zanîngeha Mardin Artuklu, Enstîtuya Zimanên Zindî, Mêrdîn, 2017.

Jaafar Hussein, Shreen, Vênê Jinê di Hozana Hevçerxa Kurdî da, Zanîngeha Mardin Artuklu, Enstîtuya Zimanên Zindî, Mêrdîn, 2015.

Jabar Abozaid, Majid, Rolê Morfemên Nivşî di Sentaksa Zimanê Kurdî de (Govera Behdînî), Zanîngeha Mardin Artuklu, Enstîtuya Zimanên Zindî, Mêrdîn, 2018.

Jafarzadeh, Mehdi, Analîza Kurmanciya Deregeza Xorasanê li gor Hêmanên Zimannasiyê, Zanîngeha Mardin Artuklu, Enstîtuya Zimanên Zindî, Mêrdîn, 2017.

Jahany, Parviz, Leyla û Mecnûna Sewadî (Metin-Lêkolîn-Şîrove), Zanîngeha Mardin Artuklu, Enstîtuya Zimanên Zindî, Mêrdîn, 2015.

Jalal Mohammed Amin, Dilshad, Ezmûna Teyyib Cebbar ya Helbest û Rexne, Zanîngeha Yüzüncü Y1l, Enstîtuya Zimanên Zindî, Wan, 2017.

Jamal Ahmad, Azhin, Raçavkirina Aliyên Derunî di Karên Darêjî di Zimanê Kurdî de, Zanîngeha Yüzüncü Y1l, Enstîtuya Zimanên Zindî, Wan, 2017.

Jameel Ismail, Abid, Rengvedana Geşbîniyê di Helbesta Nû ya Kurdî li Devera Behdînan da, Zanîngeha Mardin Artuklu, Enstîtuya Zimanên Zindî, Mêrdîn, 2015.

Jameel Mohammed, Hawkar, Binyadî Gêranewa le Dastanî Mem û Zinî Oskar Mann û Şanoyî Memê Alanî Ebdurehîm Rehmî Hekarî (Lêkolînewekî Berawirdkariyê), Zanîngeha Bingöl, Enstîtuya Zimanên Zindî, Çewlîg, 2017.

Janez Sar Çeper, Fatime, Lêkolînek li ser Helbesta Qedrî Can, Zanîngeha Mardin Artuklu, Enstîtuya Zimanên Zindî, Mêrdîn, 2014.

Kaçan, Muhammed Emin, Zazakî de Kategorîzekerdişê Edatan û Metnanê Zazakî ra Nimûneyî, Zanîngeha Mardin Artuklu, Enstîtuya Zimanên Zindî, Mêrdîn, 2018.

Kamal Yousif, Hajar, Vata di Diyaloga Karîkatêrê Kurdî da (Vekolîneka Sîmantîkî û Pragmatîkiye), Zanîngeha Mardin Artuklu, Enstîtuya Zimanên Zindî, Mêrdîn, 2014.

Kan, Ahmet, Rojnameya Kurdistanê 1898-1902 (Analîza Naverokê), Zanîngeha Mardin Artuklu, Enstîtuya Zimanên Zindî, Mêrdîn, 2018.

Kan, Güneş, Îmaja Ermenî di Romanên Kurdî yên Sovyeta Berê de, Zanîngeha Mardin Artuklu, Enstîtuya Zimanên Zindî, Mêrdîn, 2016.

Kanabi Taher, Barzan, Bas û Xwas Le Manşetî Hewal Rojnamekanî Xebat, Kurdistanî Nûwe û Rojname: Be Numûne Lêkolîneweyekî Simantîkî û Pragmatîkî, Zanîngeha Bingöl, Enstîtuya Zimanên Zindî, Çewlîg, 2018.

Kaplan, Yaşar, Destana Kela Dimdim û Xanê Lepzêrîn: Lêkolînek Edebî û Dîrokî, Zanîngeha Yüzüncü Y1l, Enstîtuya Zimanên Zindî, Wan, 2015.

Karaaslan, Mehmet Salih, 'Hedersmord' li Swêdê 'Kuştina Namûsî' li Kurdistanê, Zanîngeha Mardin Artuklu, Enstîtuya Zimanên Zindî, Mêrdîn, 2014. 
Karabayeser, Ayetullah, Zazakî di Wexti, Zanîngeha Bingöl, Enstîtuya Zimanên Zindî, Çewlîg, 2017.

Karagöz, Naci, Seçmeli Kürtçe Dersine Karşı Veli Tutumları, Zanîngeha Dicle, Enstîtuya Zanistên Civakî, Diyarbekir, 2016.

Karaman, Cevdet, Ehmed Hîlmî Elqoxî û Berhema Wî ya Rehberê Sanî Şerha Eqîda Ehmedê Xanî, Zanîngeha Muş Alparslan, Enstîtuya Zanistên Civakî, Mûş, 2017.

Karim M.Salih, Hemin, Runbêjîyê di Helbestên Ehmed Muxtar Caf de, Zanîngeha Yüzüncü Y1l, Enstîtuya Zimanên Zindî, Wan, 2016.

Kavşut, Nihat, Ji Hêla Teknîk û Mijarê ve Analîzkirina Romana Şivanê Kurmanca ya Erebê Şemo, Zanîngeha Muş Alparslan, Enstîtuya Zanistên Civakî, Mûş, 2017.

Kaya, Bülent, Feqîyê Teyran'ın Şêxê Sen'an Şiirinin İçerik Açısından İncelenmesi, Zanîngeha Dicle, Enstîtuya Zanistên Civakî, Diyarbekir, 2017.

Kerece, Fahrî, Di Çarçoveya Têgiha Neteweperwerîyê da Nirxandinek li ser Şêx Ubeydillahê Nehrî, Zanîngeha Mardin Artuklu, Enstîtuya Zimanên Zindî, Mêrdîn, 2018.

Khamo Khudhur, Shemal, Praktîzekirna Tiyûra Wergirtinê di Edebiyata Olî ya Êzdiyan da, Zanîngeha Mardin Artuklu, Enstîtuya Zimanên Zindî, Mêrdîn, 2016.

Khidhir, Mohammed, Ji bo Zarokan Çîrokên Ajalan (Mînak Çîrokên Kovara Heng 2001-2011), Zanîngeha Yüzüncü Y1l, Enstîtuya Zimanên Zindî, Wan, 2017

Kılıç, Özlem, Gramerê Zazakî de Derheqê Negatîfîye Yew Cigêrayîş, Zanîngeha Bingöl, Enstîtuya Zimanên Zindî, Çewlîg, 2015.

Kurkan, Ahmet, Mewlîdê Usman Esad Efendîyo Babijîi 'Bîyîşa Pêxemberî' (Metn û Vekenitîş), Zanîngeha Mardin Artuklu, Enstîtuya Zimanên Zindî, Mêrdîn, 2014.

Koyuncu, Hüseyin, Di Hin Dîwanên Kurdî de Bandora Tesewifê, Zanîngeha Bingöl, Enstîtuya Zimanên Zindî, Çewlîg, 2014.

Kurt, Şehmuz, Nirxandina Pirtûka Hînkirina Kurdî: Hînker -Li gorî Nêrînên Xwendekar û Mamosteyan-, Zanîngeha Mardin Artuklu, Enstîtuya Zimanên Zindî, Mêrdîn, 2015.

Laçin, Şahap, Zazakî de Zerfî û Goreyê Raweyan Şuxulnayîşê Zerfan, Zanîngeha Bingöl, Enstîtuya Zimanên Zindî, Çewlîg, 2018.

Lafte Ridha Al-Kakî, Farset, Rengdanewey Taybetmendiyekanî Sebk-î 'Iraqî le Şi'rekanî Melayê Cizîrî da, Zanîngeha Bingöl, Enstîtuya Zimanên Zindî, Çewlîg, 2017.

Mehemed Kocher, Jasim, Rehendên Derûnî di Hozanên Rojen Barnasî da, Zanîngeha Mardin Artuklu, Enstîtuya Zimanên Zindî, Mêrdîn, 2016.

Mikaeel Azeez Azeez, Saad, Surriyalîzm di Helbesta Nûxazî ya Kurdî de (bi nimûne Helbestên Sebah Rencder), Zanîngeha Bingöl, Enstîtuya Zimanên Zindî, Çewlîg, 2017.

Mohammad Hussein, Hlbeen, Pêkhateyên Diramayê di Hozanên Bedîrxan Sindî da, Zanîngeha Mardin Artuklu, Enstîtuya Zimanên Zindî, Mêrdîn, 2014. 
Mohammed Abdolqader, Shivan, Rola Gîreyan di Polguherîna Peyvê de di Kurmanciya Serî Devoka Behdînan da, Zanîngeha Mardin Artuklu, Enstîtuya Zimanên Zindî, Mêrdîn, 2016.

Mohammed Ahmed, Hariwan, Teknîka Dubarekirinê di Avakirina Rîtma Navxweyî ya Helbestên Kamîran Bedirxanî de -Dîwana Dilê Kurên Min wek Nimûne-, Zanîngeha Mardin Artuklu, Enstîtuya Zimanên Zindî, Mêrdîn, 2017.

Mohammed Ghaffar, Nergiz, Îstatîka Cihî di Romanên Sebrî Silêvanî da, Zanîngeha Mardin Artuklu, Enstîtuya Zimanên Zindî, Mêrdîn, 2014.

Mohammed Hussein, Safen, Rehendê Derûnî di Helbestên Ebdula Peşêw de, Zanîngeha Yüzüncü Y1l, Enstîtuya Zimanên Zindî, Wan, 2017.

Mohammed Othman, Hayder, Di Helbestên Melayê Bateyî da Binyada Hizr î Rûxsarê, Zanîngeha Yüzüncü Y1l, Enstîtuya Zimanên Zindî, Wan, 2016.

Mohammed Rashid, Hawkar, Teknîka Vegotinê di Romanê de (Mîrname ya Jan Dost Wek Mînak), Zanîngeha Yüzüncü Yıl, Enstîtuya Zimanên Zindî, Wan, 2016.

Muhammed Mawlud, Qabeel, Rola Rojnama Bizav di Pêşxistina Helbesta Kurdî li Devera Behdînan, Zanîngeha Yüzüncü Y1l, Enstîtuya Zimanên Zindî, Wan, 2017.

Muhialdien al-Barazanji, Aram, Rengdanên Ola Îslamî ya di Helebestên Nalî de, Zanîngeha Yüzüncü Y1l, Enstîtuya Zimanên Zindî, Wan, 2017.

Mushir Salih, Tara, Hawwata û Firewata le Pendekanî Pîremêrdî Şaîr, Zanîngeha Mardin Artuklu, Enstîtuya Zimanên Zindî, Mêrdîn, 2016.

Mustafa Hamad, Jamal, Dîroka Wêjeya Kurdî a Merif Xeznedar ̂̂ rol û Taybetmendiyên Wî, Zanîngeha Yüzüncü Y1, Enstîtuya Zimanên Zindî, Wan, 2017.

Naderî Moghadam, Shatav, Şi'rên Şairên Yarsan û Hizrê Yarî, Zanîngeha Yüzüncü Y1l, Enstîtuya Zimanên Zindî, Wan, 2016.

Najeb Abdulrazaq, Jegr, Binyatê Honerî di Dastana Zembîlfroş ya Feqiyê Teyran û Miradxanê Bayezînî da, Zanîngeha Mardin Artuklu, Enstîtuya Zimanên Zindî, Mêrdîn, 2017.

Nawzad Faqe Ibrahim, Hana, Gireke Rêzimanî û Ferhengiyekanî Kar le Zimanî Kurdî û Farisî da, Zanîngeha Bingöl, Enstîtuya Zimanên Zindî, Çewlîg, 2017.

Nori Omer, Salam, Rolê Kovara Metîn di Pêşxistina Vekolînên Edebî de, Zanîngeha Yüzüncü Y1l, Enstîtuya Zimanên Zindî, Wan, 2017.

Öçal, Serdar, Awayê Lêkirina Navan li Herêma Dêrîkê (Lêkolîneke OnomastîkSosyolojîk), Zanîngeha Mardin Artuklu, Enstîtuya Zimanên Zindî, Mêrdîn, 2016.

Ölmez, Cumhur, Mem ̂̂ Zîneke bi Hewramî (Tekst-Vekolîn), Zanîngeha Mardin Artuklu, Enstîtuya Zimanên Zindî, Mêrdîn, 2018.

Omar Ahmed, Honar, Evîn û Hezkirina Jinê di Helbestên Mistefa Begê Kurdî da, Zanîngeha Yüzüncü Y1l, Enstîtuya Zimanên Zindî, Wan, 2017.

Omar Ali, Sarhang, Bingehê Karakter di Romana Hesar û Segên Bavê Min ya Şêrzad Hesen de, Zanîngeha Yüzüncü Y1, Enstîtuya Zimanên Zindî, Wan, 2016.

Omar Mahmoud, Barzo, Şîrovekirineke Dengsazî û Fonolojî di Kurdiya Kurmancî de, Zanîngeha Mardin Artuklu, Enstîtuya Zimanên Zindî, Mêrdîn, 2016. 
Omer Ahmad el Shateera, Koser, Şakelîyekan û Roliyan le Şi'rî Kurdî da; Şêx Ehmed be Nimûne, Zanîngeha Bingöl, Enstîtuya Zimanên Zindî, Çewlîg, 2018.

Omer Sadiq, Avan, Di Helbestên Goran de Tasîra Rêbazên Pernasîzimê û Sembolîzimê, Zanîngeha Yüzüncü Y1l, Enstîtuya Zimanên Zindî, Wan, 2017.

Öner, Ahmet, Di Edebiyata Gelêrî ya Kurdî da Di’a û Nifir, Zanîngeha Yüzüncü Y1l, Enstîtuya Zimanên Zindî, Wan, 2017.

Orak Reşitoglu, Sevda, Helbestvanên Jin di Edebiyata Yarsanan de, Zanîngeha Mardin Artuklu, Enstîtuya Zimanên Zindî, Mêrdîn, 2016.

Orkin, Şeyhmus, Di Berhemên Feqiyê Teyran de Hêmanên Tesewufî, Zanîngeha Muş Alparslan, Enstîtuya Zanistên Civakî, Mûş, 2015.

Othman Qader, Samad, Zimanê Ragihandinê di Nuçeyên Rojname Elektronîk de, Zanîngeha Yüzüncü Y1l, Enstîtuya Zimanên Zindî, Wan, 2017.

Özcan, Mulazım, Di Salên 1980-2000an de li Tirkîyeyê Rewşa Ziman û Edebiyata Kurdî û Têkiliya Wan li gel Tevgerên Civakî yên Kurdan, Zanîngeha Yüzüncü Yı1, Enstîtuya Zimanên Zindî, Wan, 2018.

Öztürk, İrfan, Hîmên Helbesta Kovara Tîrêjê, Zanîngeha Mardin Artuklu, Enstîtuya Zimanên Zindî, Mêrdîn, 2014.

Öztürk, Serdar, Di Tradîsyona Dengbêjiya Kurdî de Şakiro (Jiyan û Berhem), Zanîngeha Mardin Artuklu, Enstîtuya Zimanên Zindî, Mêrdîn, 2014.

Pertev, Ramazan, Mîrsadu'l-Etfal (Şahrahê Kûdekan) Ferhenga Menzûm a KurdîFarisî (Vekolîn-Tekst), Zanîngeha Mardin Artuklu, Enstîtuya Zimanên Zindî, Mêrdîn, 2012.

Pesen, Abdurahim, Helbesta Arjen Arî (Naverok-Şêwe-Binyad), Zanîngeha Bingöl, Enstîtuya Zimanên Zindî, Çewlîg, 2015.

Polat, Edip, Di Çend Pexşanên Kurmancî de Evînên Efsanevî, Zanîngeha Mardin Artuklu, Enstîtuya Zimanên Zindî, Mêrdîn, 2014.

Polat, Leyla, Wekî Kirdeyekê Hebûn û Temsîliyeta Jinan (Awirtêdaneke Rexneyî a Femînîst bo Berhemên Dilawer Zeraq), Zanîngeha Yüzüncü Y1l, Enstîtuya Zimanên Zindî, Wan, 2017.

Rashad Qader, Zeyad, Bi Zaravayê Soranî Helbestên Zarokan li Edebê Kurdî de (Zêwer, Goran, Letîf Helmet û Emîn Mihemed), Zanîngeha Yüzüncü Y1l, Enstîtuya Zimanên Zindî, Wan, 2016.

Rasool Aba Baker Mangurî, Mangoor, Bingeha Wêneyên Hunerî di Helbestên Hêmin de, Zanîngeha Yüzüncü Y1l, Enstîtuya Zimanên Zindî, Wan, 2016.

Rojdar Yıldız, Reşit, Di Edebiyata Zarokan de Çîrok, Zanîngeha Yüzüncü Yı1, Enstîtuya Zimanên Zindî, Wan, 2017.

Safeen Sadi Saadi, Sahand, Rehendên Dîrokî Di Romana "Xewna Zelamên Îranî" Mardîn Îbrahîmê, Zanîngeha Yüzüncü Y1l, Enstîtuya Zimanên Zindî, Wan, 2016.

Sagvan, Omeed, Xwekuştin di Romanên Kovan Sindî de, Zanîngeha Mardin Artuklu, Enstîtuya Zimanên Zindî, Mêrdîn, 2017.

Saiwan Ahmed, Omar, Edebiyatî Enfal le Govare Kurdiyekanî Nawçeyî Germiyan da (1992-2012), Zanîngeha Mardin Artuklu, Enstîtuya Zimanên Zindî, Mêrdîn, 2016. 
Saleh Hussein, Nadhim, Kovargeriya Zarokan li Başûrê Kurdistanê (Mînak: Kepir), Zanîngeha Yüzüncü Y1l, Enstîtuya Zimanên Zindî, Wan, 2018.

Saleh Hussein, Nadhim, Kovargeriya Zarokan li Başûrê Kurdistanê (Mînak: Kepir), Zanîngeha Yüzüncü Y1l, Enstîtuya Zimanên Zindî, Wan, 2018.

Salih Shaduman, Omar, Cuwankarî le Şi'rî Hewçerxî Kurdî da, Zanîngeha Bingöl, Enstîtuya Zimanên Zindî, Çewlîg, 2018.

Samuk, Hidayet, Servi Bölgesi Folkloru, Zanîngeha Bingöl, Enstîtuya Zimanên Zindî, Çewlîg, 2018.

Samur, Aziz, Destana Zembîlfiroş û Gulxatûnê, Zanîngeha Mardin Artuklu, Enstîtuya Zimanên Zindî, Mêrdîn, 2013.

Şanlı, Esat, Têvernayîşê Kurmancî û Zazakî: Nimuneyê Licê û Hezanê, Zanîngeha Mardin Artuklu, Enstîtuya Zimanên Zindî, Mêrdîn, 2017.

Saydun, Edip, Teşe û Ciwankariyên Wêjeyî di Dîwana Feqiyê Teyran de, Zanîngeha Yüzüncü Y1l, Enstîtuya Zimanên Zindî, Wan, 2018.

Sayım, İlyas, Kurmancî ve Hintçede Ergatif Yapı Üzerine Bir İnceleme, Zanîngeha Muş Alparslan, Enstîtuya Zanistên Civakî, Mûş, 2017.

Sezer, Müslih, Dîwançeya Seyfiyê Şoşî (Metn û Lêkolîn), Zanîngeha Mardin Artuklu, Enstîtuya Zimanên Zindî, Mêrdîn, 2016.

Shirinov, Nofal, Folklora Kurdên Azerbaycanê, Zanîngeha Mardin Artuklu, Enstîtuya Zimanên Zindî, Mêrdîn, 2017.

Shukur Mahmood, Imad, Têgeh û Zaravayê Îrfanî di Helbestên Fexredîn Eraqî û Mihwî de, Zanîngeha Yüzüncü Y1l, Enstîtuya Zimanên Zindî, Wan, 2017.

Siaband Abbas, Reber, Efsane di Grûba Edebî ya Nûkirin Her $\hat{u}$ Her da Hizirvan Ebdulla Wek Nimûne, Zanîngeha Mardin Artuklu, Enstîtuya Zimanên Zindî, Mêrdîn, 2018.

Söylemez, Semra, Melekan, Gaz ve Muradan Köyleri Zazacasının Ses Değişimi Yönünden Karşilaştırılması, Zanîngeha Bingöl, Enstîtuya Zimanên Zindî, Çewlîg, 2014.

Subaşı, Kenan, Ji bo Zarokan di Fêrkirina Kurdî de Rola Mamikan, Zanîngeha Mardin Artuklu, Enstîtuya Zimanên Zindî, Mêrdîn, 2014.

Sulaiman Ismael, Ismael, Rengvedana Zindanê di Romanên Selam 'Ebdulla de, Zanîngeha Mardin Artuklu, Enstîtuya Zimanên Zindî, Mêrdîn, 2018.

Taher Bazid, Berqee, Hevalnav di Navbera Zimanê Kurdî (Kurmanciya Serî) û Tirkî da, Zanîngeha Mardin Artuklu, Enstîtuya Zimanên Zindî, Mêrdîn, 2017.

Tahir Sabir, Derin, Şi'riyetî Şi'rî Kosarî, Zanîngeha Bingöl, Enstîtuya Zimanên Zindî, Çewlîg, 2018.

Taman, Bahattin, Daçek di Zaravayê Kurmancî da, Zanîngeha Mardin Artuklu, Enstîtuya Zimanên Zindî, Mêrdîn, 2018.

Tanrıkulu, Veysel, Kürtçe Masallar ile Grimm Kardeşler Masallarının Motifler Açısından Karşılaştırılması, Zanîngeha Dicle, Enstîtuya Zanistên Civakî, Diyarbekir, 2017. 
Tarduş, Ibrahim, Bikaranîna Çîrokên Kurdî di Perwerdeya Zarokan de, Zanîngeha Mardin Artuklu, Enstîtuya Zimanên Zindî, Mêrdîn, 2015.

Taş, Çetin, Dengsaziya Devoka Çaldiranê, Zanîngeha Mardin Artuklu, Enstîtuya Zimanên Zindî, Mêrdîn, 2015.

Taş, Melik, Lêkolînek li ser Çanda Devkî ya Çaldiranê, Zanîngeha Muş Alparslan, Enstîtuya Zanistên Civakî, Mûş, 2018.

Tawfeeq Raof, Nawshirwan, Binyata 'Struktûra Bûyerê di Romana Evara Perwaneyê ya Bextiyar Elî de, Zanîngeha Yüzüncü Y1l, Enstîtuya Zimanên Zindî, Wan, 2016.

Tektaş, İhsan, Mintiqaya Licê ra Diwês Sanikî û Versîyonê Înan: Pêveronayîş û Tehlîl, Zanîngeha Mardin Artuklu, Enstîtuya Zimanên Zindî, Mêrdîn, 2018.

Tosun, Türkan, Edebiyata Zarokan di Kovara Nûbiharê de (1992-2010), Zanîngeha Bingöl, Enstîtuya Zimanên Zindî, Çewlîg, 2017.

Tunç, Vehbi, Gılgamış Destanı'nda Sümerce ile Kürtçe’nin Sosyo-linguistik Bağlantısı, Zanîngeha Dicle, Enstîtuya Zanistên Civakî, Diyarbekir, 2016.

Turan, Cihan, Dîwana Fethî (Edîsyon, Metn, Krîtîk), Zanîngeha Bingöl, Enstîtuya Zimanên Zindî, Çewlîg, 2017.

Ulugana, Sedat, Mîrektiya Bitlîsê di Êwra Evdal Xan de (1618-1664), Zanîngeha Mardin Artuklu, Enstîtuya Zimanên Zindî, Mêrdîn, 2015.

Üneşi, Aydın, Tesrîfa Teremaxî, Zanîngeha Mardin Artuklu, Enstîtuya Zimanên Zindî, Mêrdîn, 2016.

Varol, Murat, Dîwanê Melayê Cebexçurî (Metn û Tehlîl), Zanîngeha Bingöl, Enstîtuya Zimanên Zindî, Çewlîg, 2016.

Veroj, Sait, Veracêkerdena Gramerê Zazakî û Kurmancî: Dîyalekt, Alfabe û Fonetîk, Morfolojî, Zanîngeha Mardin Artuklu, Enstîtuya Zimanên Zindî, Mêrdîn, 2014.

Yaman, Raif, Fonemên Kurdî yên Kurdzan û Gerokên Ewrûpî û Amerîkî (17871887), Zanîngeha Mardin Artuklu, Enstîtuya Zimanên Zindî, Mêrdîn, 2016.

Yavuzer, Mehmet Nur, Baba Tahir di Wêjeya Kurdî de, Zanîngeha Yüzüncü Yı1, Enstîtuya Zimanên Zindî, Wan, 2016.

Yergin, Mehmet, Mewlîdê Mela Ehmedê Xasî: "Mewlidu'n-Nebiyyi'l-Qureyşiyyî" (Metn-Wekenitiş), Zanîngeha Mardin Artuklu, Enstîtuya Zimanên Zindî, Mêrdîn, 2015.

Yeşilçınar, Fehmi, Jiyan û Kilamên Dengbêj Ahmed Alîksan, Zanîngeha Muş Alparslan, Enstîtuya Zanistên Civakî, Mûş, 2015.

Yeşilkaya, Şahap, Edebiyatê Kirdkî (Zazakî) de Mewlid û Mehemed 'Elî Hunî, Zanîngeha Bingöl, Enstîtuya Zimanên Zindî, Çewlîg, 2014.

Yeşilmen, Davut, Temaya Sirgûnê di Çar Romanên Kurdî (Kurmancî) de, Zanîngeha Mardin Artuklu, Enstîtuya Zimanên Zindî, Mêrdîn, 2014.

Yıldırımçakar, Adil, Bedîuzaman Seîdê Kurdî û Projeya Wî ya Medresetuzehra, Zanîngeha Yüzüncü Y1l, Enstîtuya Zimanên Zindî, Wan, 2016. 
Yıldırımçakar, Mehmet, Heyranok di Edebiyata Kurdî ya Gelêrî de Mînaka Herêma Wanê, Zanîngeha Muş Alparslan, Enstîtuya Zanistên Civakî, Mûş, 2017.

Yıldırımçakar, Ziyattin, Werger wek Kirineke Çandî, li ser Riyên Vergernasiyê ber bi Kurdolojiyê ve, Zanîngeha Mardin Artuklu, Enstîtuya Zimanên Zindî, Mêrdîn, 2016.

Yıldız, Ayhan, Qewlê Hespê Reş, Zanîngeha Mardin Artuklu, Enstîtuya Zimanên Zindî, Mêrdîn, 2015.

Yıldız, Reşit Rojdar, Di Edebiyata Zarokan de Çîrok, Zanîngeha Yüzüncü Y11, Enstîtuya Zimanên Zindî, Wan, 2017.

Yıldızhan, Veysel, Bi Tarîxê Nusîyanena Xo ya Tewr Kehene Çekuyê Kirmanckî (Zazakî) (1798-1903), Zanîngeha Mardin Artuklu, Enstîtuya Zimanên Zindî, Mêrdîn, 2017.

Y1lmaz, Abdurrahman, Zazaca-Türkçe Sözlük, Genç-Bingöl Yöresi, Zanîngeha Bingöl, Enstîtuya Zimanên Zindî, Çewlîg, 2015.

Y1lmaz, Ferhat, Berawirdkirinek li ser Şivanê Kurmanca û Sêbareya Maksîm Gorkî, Zanîngeha Mardin Artuklu, Enstîtuya Zimanên Zindî, Mêrdîn, 2015.

Yonat, Mehmet, Kovara Nûdemê û di Kovara Nûdemê de Şopên Surgunê, Zanîngeha Muş Alparslan, Enstîtuya Zanistên Civakî, Mûş, 2015.

Zilan, Bilal, Di Kitabê Muhemmedê Şêx Ensarî: "Raro Raşt" û "Melûmatê Dînîye" (Metn û Cigêrayîş), Zanîngeha Mardin Artuklu, Enstîtuya Zimanên Zindî, Mêrdîn, 2016.

\section{Encam}

Di vê bîbliyografyayê de me dît ku hem tezên beşa Ziman û Edebiyata Kurdî û hem jî Ziman û Çanda Kurdî ji 2012an pê ve xwendekarên masterê mezûn dikin. Di navbera salên 2012-2018an de li zanîngehên Bingöl, Dicle, Mardin Artuklu, Muş û Yüzüncü Y1lê bi tevahî 241 tez hatine parastin û derçûne. Herçiqas me di analîza xwe de behs nekiribe jî tezên di van herdu beşan bêtir bi zimanê kurdî hatine nivîsîn. Di nav zaravayên kurdî de herî zêde bi kurmancî, piştre bi kurmanckî û dûre jî bi soranî tez hene. Ji hêla zimên ve, nemaze zanîngeha Dicleyê bala mirov dikişîne ser xwe. Ji ber hinek astengiyên rêziknameya zanîngehê tezên wir bi tirkî tên nivîsîn.

Xwendekarên ku di wan herdu beşan de dixwînin dikarin di sehayên cûrbicûr de lêkolînan bikin û tezên xwe binivîsin. Tezên ku di wan beşan de hatine nivîsîn û biwaranên wan li gorî alfabetîk ev in: Bîbliyografya, civaknasî, çapemenî, dîrok, edebiyata berawirdî, edebiyata klasîk, edebiyata nû, edebiyata zarokan, ferhengnasî, folklor, jînenîgerî, perwerde, wergernasî û zimannasî. Di nav van biwaran de yên herî zêde derketine pêş bi rêzê ve edebiyata nû $(27 \%)$, folklor $(20 \%)$ û edebiyata klasîk $(17 \%)$ û zimannasî (16\%) ne. Dîsa li gor van rêjeyan biwarên ku lê kêm xebat hatine kirin jî̀ wiha ne: Wergernasî (0\%), dîrok (1\%), ferhengnasî (1\%), civaknasî (1\%). Herwiha biwarên din jî bi van rêjeyan di tabloya tezan de bi cih girtine: Bîbliyografya ( $2 \%)$, edebiyata berawirdî ( $2 \%)$, edebiyata zarokan (2\%), jînenîgarî ( $2 \%)$, perwerde (3\%) û çapemenî (6\%). Li gor van rêjeyan mirov dikare bibêje; biwarên ku rêjeya wan kêm in divê bêtir bala xwendekaran bikişine û xwendekar beraliyê van biwaran bin, da ku xebatên zêdetir derkevin û kêmasiyên van biwaran de bên temamkirin. Dîsa ji bilî van kategoriyên jorîn, hersê zanistên bingehîn ên zimannasî, dîrok û erdnigarî bi hev re, bi awayekî organîze û paralel divê bên meşandin, ligel xwe jî cih bidin zanistên 
antropolojî û civaknasiyê. Mamoste û xwendekarên vê beşê divê ji bîr nekin ku sehaya kurdolojiyê qadeke berfireh e û wekî her beşên din ên zanistên civakî hewcehiya wê jî bi hemû biwaran heye.

Xebatên bi rengê bîbliyografîk di kar û lêkolînên akademîk de gelekî girîng in lewra bi xêra wan xebatan lêkolînên akademîk hem xwe dubare nakin hem jî ji xebatên berî xwe haydar dibin. Di vê çarçoveyê de armanca vê xebatê jî ev bû ku di vî warî de lêkolîner û xwendekaran re bibe xizmetek.

\section{Jêder}

Adak, A., Acar, H., Aykaç, Y. (2017). "Bîbliyografyaya Melayê Cizîrî”, Mukaddime, 8(Özel Sayı 1), r. 171-199.

Aykaç, Y. (2017). "Bîbliyografyaya Tezên Beşên Kurdolojiyê yên li Turkiyeyê (20112016)", JMS, c. 2/1, r. 119-132.

Durmuş, İ. (2002). "Kitabiyat”, DİA, c. 26. İstanbul, r. 83-85.

Ertekin, M. Z., Güzel, Ş. (2019). "Xebatên Kurdolojîyê li Zanîngeha Bîngolê (20142018)", Mukaddime, 10(1), r. 161-193.

Keskin, N. (2018). "Kovargeriya Akademîk a Kurdî li Turkiyeyê û Pirsgirêkên Wê", Mukaddime, j. 9 (2), r. 31-47.

Keskin, N. (2018). "Serboriya Akademiya Kurdî li Turkiyeyê û Pirsgirêkên Wê", eŞarkiyat, c. 10, j. 1(19)/Nisan , r. 471-485.

Malclés, L-N., Lhèriter A., Acaroglu, M. T. (2003). Batı'da ve Türkiye'de Kaynakça Tarihi, İletişim, İstanbul.

https://tez.yok.gov.tr/UlusalTezMerkezi/ (01.03.2019).

https://www.etymonline.com/word/bibliography\#etymonline_v_11116(08.03.2019).

https://en.oxforddictionaries.com/definition/us/bibliography(08.03.2019).

https://www.vajehyab.com/?q=تفهر ست (08.03.2019). 